\title{
Development of graphene-based enzymatic biofuel cells: A minireview
}

Tang, Jing; Yan, Xiaomei; Engelbrekt, Christian; Ulstrup, Jens; Magner, Edmond; Xiao, Xinxin; Zhang, Jingdong

\section{Published in:}

Bioelectrochemistry

Link to article, DOI:

10.1016/j.bioelechem.2020.107537

Publication date:

2020

Document Version

Peer reviewed version

Link back to DTU Orbit

Citation (APA):

Tang, J., Yan, X., Engelbrekt, C., Ulstrup, J., Magner, E., Xiao, X., \& Zhang, J. (2020). Development of graphene-based enzymatic biofuel cells: A minireview. Bioelectrochemistry, 134, [107537].

https://doi.org/10.1016/j.bioelechem.2020.107537

\section{General rights}

Copyright and moral rights for the publications made accessible in the public portal are retained by the authors and/or other copyright owners and it is a condition of accessing publications that users recognise and abide by the legal requirements associated with these rights.

- Users may download and print one copy of any publication from the public portal for the purpose of private study or research.

- You may not further distribute the material or use it for any profit-making activity or commercial gain

- You may freely distribute the URL identifying the publication in the public portal

If you believe that this document breaches copyright please contact us providing details, and we will remove access to the work immediately and investigate your claim 


\section{Journal Pre-proofs}

Development of graphene-based enzymatic biofuel cells: A minireview

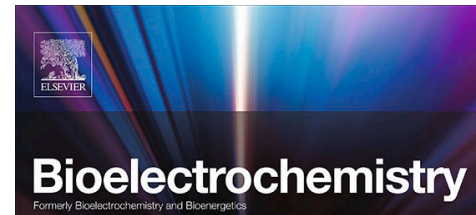

Jing Tang, Xiaomei Yan, Christian Engelbrekt, Jens Ulstrup, Edmond

Magner, Xinxin Xiao, Jingdong Zhang

PII:

S1567-5394(19)30865-5

DOI:

https://doi.org/10.1016/j.bioelechem.2020.107537

Reference:

BIOJEC 107537

To appear in:

Bioelectrochemistry

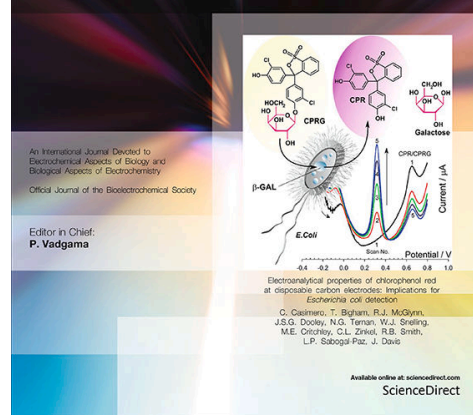

Received Date: $\quad 14$ January 2020

Revised Date: $\quad 15$ April 2020

Accepted Date: $\quad 15$ April 2020

Please cite this article as: J. Tang, X. Yan, C. Engelbrekt, J. Ulstrup, E. Magner, X. Xiao, J. Zhang, Development of graphene-based enzymatic biofuel cells: A minireview, Bioelectrochemistry (2020), doi: https://doi.org/ 10.1016/j.bioelechem.2020.107537

This is a PDF file of an article that has undergone enhancements after acceptance, such as the addition of a cover page and metadata, and formatting for readability, but it is not yet the definitive version of record. This version will undergo additional copyediting, typesetting and review before it is published in its final form, but we are providing this version to give early visibility of the article. Please note that, during the production process, errors may be discovered which could affect the content, and all legal disclaimers that apply to the journal pertain.

(C) 2020 Published by Elsevier B.V. 


\title{
Development of graphene-based enzymatic biofuel cells: A minireview
}

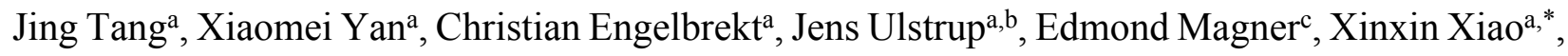
Jingdong Zhanga,*

aDepartment of Chemistry, Technical University of Denmark, Kongens Lyngby 2800, Denmark

bKazan National Research Technological University, K. Marx Str., 68, 420015 Kazan, Republic of Tatarstan, Russian Federation

'Department of Chemical Sciences and Bernal Institute, University of Limerick, Limerick V94 T9PX, Ireland

*Corresponding authors: Xinxin Xiao (xixiao@kemi.dtu.dk) and Jingdong Zhang (jz@,kemi.dtu.dk)

\begin{abstract}
Enzymatic biofuel cells (EBFCs) have attracted increasing attention due to their potential to harvest energy from a wide range of fuels under mild conditions. Fabrication of effective bioelectrodes is essential for practical EBFCs application. Graphene possesses unique physiochemical properties making it an attractive material for the construction of EBFCs. Despite these promising properties, graphene has not been used for EBFCs as frequently as carbon nanotubes, another nanoscale carbon allotrope. This review focuses on current research progress in graphene-based electrodes, including electrodes modified with graphene derivatives and graphene composites, as well as free-standing graphene electrodes. Particular features of graphenebased electrodes such as high conductivity, mechanical flexibility and high porosity for bioelectrochemical applications are highlighted. Reports on graphene-based EBFCs from the last five years are summarized, and perspectives for graphene-based EBFCs are offered.
\end{abstract}

Keywords: graphene; bioelectrodes; enzyme electrochemistry; bioelectrochemistry; enzymatic biofuel cell 


\section{Introduction}

Enzymatic biofuel cells (EBFCs) are electrochemical devices, in which enzymes are employed to catalyze the oxidation of fuel molecules and/or the reduction of dioxygen or peroxide for electricity generation (Fig. 1). In comparison to conventional fuel cells (FCs) [1-5], EBFCs operate under mild conditions (i.e. ambient temperature, neutral $\mathrm{pH}$ ), instead of strongly acidic/alkaline environments. EBFCs can be considered as sustainable and renewable considering that enzymatic catalysts are used rather than scarce noble metals. Fuels such as starch, glucose, fructose and lactate for EBFCs are also abundant in nature. Benefiting from the high selectivity of enzymes toward their substrates, expensive membrane separators can be avoided if the enzymes are immobilized, offering relatively simple fuel cell configurations. These advantages make EBFCs suitable for applications such as self-powered biosensors using power output as the analytical signal $[6,7]$, implantable [8-10] and wearable [11, 12] power sources fuelled by endogenous biological substances, as well as portable power sources [13].

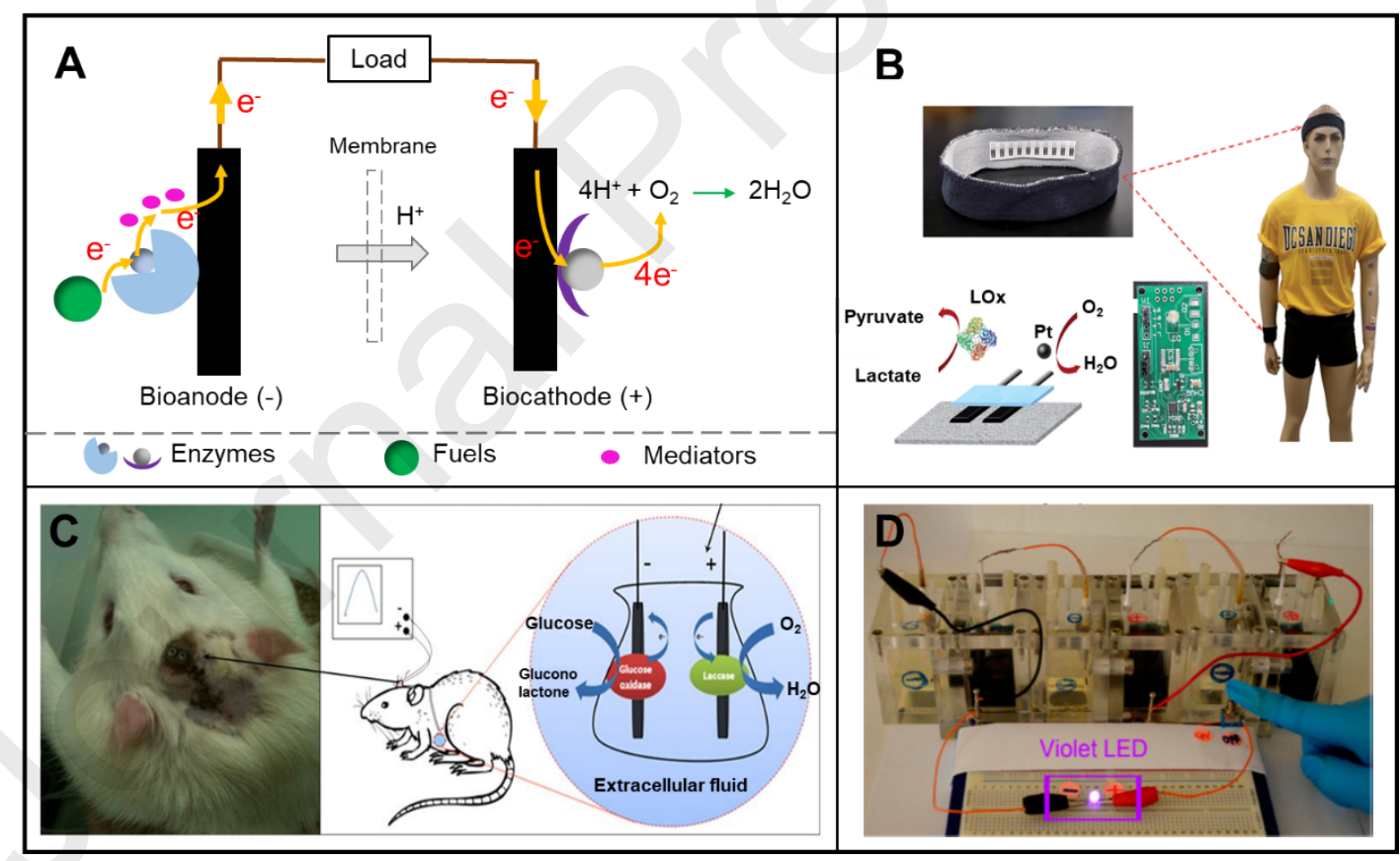

Fig. 1. (A) Schematic illustration of an EBFC with a bioanode operating with mediated electron transfer (MET), and a biocathode operating with direct electron transfer (DET). EBFC applications as (B) wearable [11], (C) implantable [10] and (D) portable power sources [14]. Reprinted with permission from ref. [10, 11, 14]. Copyright 2014 Royal Society of Chemistry; Copyright 2013 Springer Nature; Copyright 2014 American Chemical Society. 
However, insufficient open circuit voltage (OCV), low power output and poor stability of EBFCs are challenges in practical applications [15]. To address these obstacles, it is important to consider the following fundamental issues: (1) the achievement of efficient electronic communication between the active centers of enzymes and electrode surfaces; and (2) maintenance of the electrocatalytic activity of immobilized enzymes on the electrode surface. Interfacial electron transfer (ET) between the enzyme active site and the electrode surface is the core of the operation of EBFCs. Depending on whether external redox molecules are involved or not, the ET process can be classified into mediated ET (MET) and direct ET (DET) (Scheme 1). MET is a system in which a mediator molecule is oxidized or reduced by reacting with the enzyme active site, and subsequently re-formed on the electrode surface by fast ET. DET entails direct communication between the enzymes and the electrode by electron tunneling, correlated directly to the enzyme active site proximity with suitable orientation of the enzyme relative to the electrode surface.

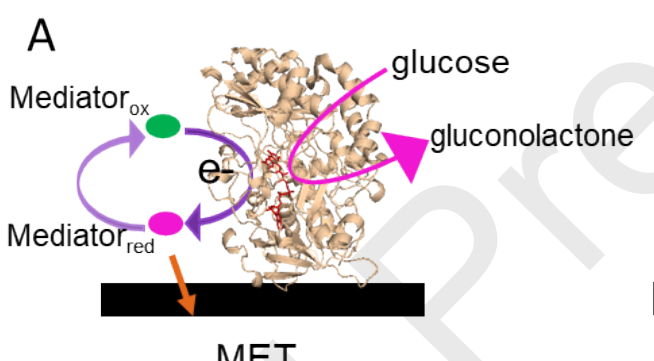

MET
B

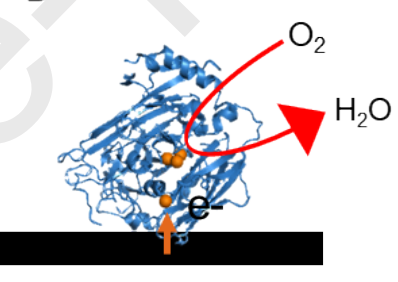

DET

Scheme 1. Schematic illustration of representative MET and DET processes between the enzyme and the electrode surface at enzymatic bioelectrodes: (A) MET from the bioanode surface through a redox mediator to glucose oxidase (GOx, PDB: 1cf3), and (B) DET from a biocathode surface to bilirubin oxidase (BOx, PDB: $2 \mathrm{xxl}$ ), catalytic copper centers are highlighted in orange color.

The instability of enzyme electrodes is typically a consequence of lack of intrinsic stability of the enzyme itself or enzyme leaching from the electrode surface due to weak enzyme/electrode interactions [16]. The enzyme immobilization technique employed, such as adsorption, covalent binding, and encapsulation, etc., determines the stability of enzymatic bioelectrodes. Adsorption, considered as the simplest and mildest technique, entails immobilization of enzymes on the electrode surface via non-covalent interactions such as van der Waals and electrostatic interactions [17]. Adsorption can retain the intrinsic activity of the enzyme, but the enzyme molecules tend to leach from electrode surfaces [18]. Covalent binding of enzymes to electrode surfaces minimizes enzyme leaching but may lead to partial denaturation of biomolecules. Site-directed immobilization of engineered enzymes can provide precise control of the orientation of the enzyme 
on the electrode surface, resulting in optimized performance [19-21]. This technique was used to produce cellobiose dehydrogenase $(\mathrm{CDH})$ bioelectrodes, which retained their catalytic currents for at least two months [20]. Entrapping enzymes into polymer matrices or inorganic frameworks on the electrode surface is another useful method for enzyme immobilization, which can reduce the amount of enzyme leaching and avoid enzyme denaturation. It has been reported that alcohol dehydrogenase entrapped in micellar polymers retained its activity after 45 days [22, 23]. Furthermore, many enzymes have been entrapped in sol-gel matrices, some of which contain redox moieties (Os or ferrocene-based complexes) or embedded conductive nanomaterials [24-26]. Apart from the enzyme immobilization techniques, other factors such as enzyme environment affect the lifetime of bioelectrodes. It has been proposed that stabilization can also be improved when the enzyme is confined in a three-dimensional (3D) matrix or closely surrounded by nanomaterials [27-29].

The introduction of conductive nanomaterials can significantly improve the performance of enzymatic bioelectrodes and therefore of EBFCs [15, 30]. Carbon-based nanomaterials, for example, CNTs, are widely used in enzyme electrochemistry [31]. As noted, graphene, featuring the ideal one-atom-thick sheet of $\mathrm{sp}^{2}$ bonded carbon atoms in a honeycomb lattice, is an excellent electrode candidate due to its robust mechanical strength, high electronic conductivity and large specific surface area [32-34]. These properties can be utilized to facilitate DET between the active site of the enzyme and the electrode surfaces as well as increase enzyme loading [35]. However, an atomically flat electrode (roughness factor of 1), cannot sustain a sufficient enzyme loading for most practical uses, implying that 3D aspects could be incorporated in the electrode design. 3D graphene-based electrodes with a high porosity and enhanced fuel diffusion rates for EBFCs can be fabricated [36, 37]. Despite these attractive properties, application of graphene based EBFCs as power sources is still at an early stage [38, 39]. There are only few reviews on the potential of graphene to improve the performance of enzymatic bioelectrodes and EBFCs published several years ago [40-42]. A timely review on graphene based EBFCs is therefore appropriate.

The present report covers recent developments and applications of graphene-based bioelectrodes in EBFCs with a focus on graphene-based electrodes for enzyme immobilization. Fabrication routes for graphene-based electrodes, including graphene derivatives, graphene composites, and free-standing graphene electrodes, are summarized. Features of graphene-based electrodes such as high conductivity, good flexibility, and high porosity for bioelectrochemistry applications are 
particularly highlighted. Reports on graphene-based EBFCs published over the last five years have been evaluated based on performance parameters such as power output and lifetime. Further perspectives for the field are also offered and discussed.

\section{Graphene-based electrodes}

As a $2 \mathrm{D}$ sheet with $\mathrm{sp}^{2}$ hybridized carbon atoms, structurally perfect graphene displays unique properties such as high electronic conductivity $\left(2-65 \mathrm{~S} \mathrm{~cm}^{-1}\right)$ [43-46], light weight and therefore high specific surface area (up to $\sim 2600 \mathrm{~m}^{2} \mathrm{~g}^{-1}$ ) [47], and mechanical strength, which together make it a highly attractive electrode material [40, 48]. The properties of graphene depend on preparation and assembly methods. Mechanical exfoliation [49], epitaxial growth [50], chemical vapour deposition (CVD) [51-54], un-zipping of CNTs [55], $\mathrm{Ni}^{2+}$-exchange/KOH activation [56], and reduction of chemically produced graphene oxide (GO) $[57,58]$ are general routes for graphene production. Mechanical exfoliation was the first reported method to isolate graphene sheets from pyrolytic graphite, but is not suitable for large-scale production [34]. CVD is attractive since it can produce "pure" and high-quality graphene with large area and specific functionalized atoms or groups on solid surfaces, but its usage is limited by high cost [52]. Un-zipping of CNTs and $\mathrm{Ni}^{2+}$-exchange/KOH activation are delicate processes and not applied widely in bioelectrochemistry. An inexpensive and easily scalable fabrication method relies on the reduction of GO obtained from the oxidation and subsequent exfoliation of graphite [41]. This 'wet chemical' method is highly suitable for further chemical and biochemical modification. After a thermal [59], chemical [60] or electrochemical [57,61] reduction process, the conductivity of GO can be enhanced via restored $\mathrm{sp}^{2}$ conjugation. Reduced GO (RGO) nanosheets can also be prepared on the surface of carbon fibers by in situ electrochemical procedures consisting of oxidative and reductive steps to yield surface supported RGO (Fig. 2) [62]. RGO sheets possess considerable amounts of defects and disordered structures, different from the "ideal" graphene. The direct utilization of graphene in bioelectrochemical applications suffers from irreversible $\pi$ - $\pi$ stacking aggregation and loss of active surface area. Surface modification with functional groups is needed to achieve specific properties. Physicochemical properties such as hydrophilicity and surface charge, which can be tuned by functionalization, affect further the performance of the enzymatic bioelectrodes. Free-standing graphene electrodes have emerged recently as promising support 
materials for wearable and implantable biomedical devices due to their mechanical robustness and flexibility (Fig. 2).

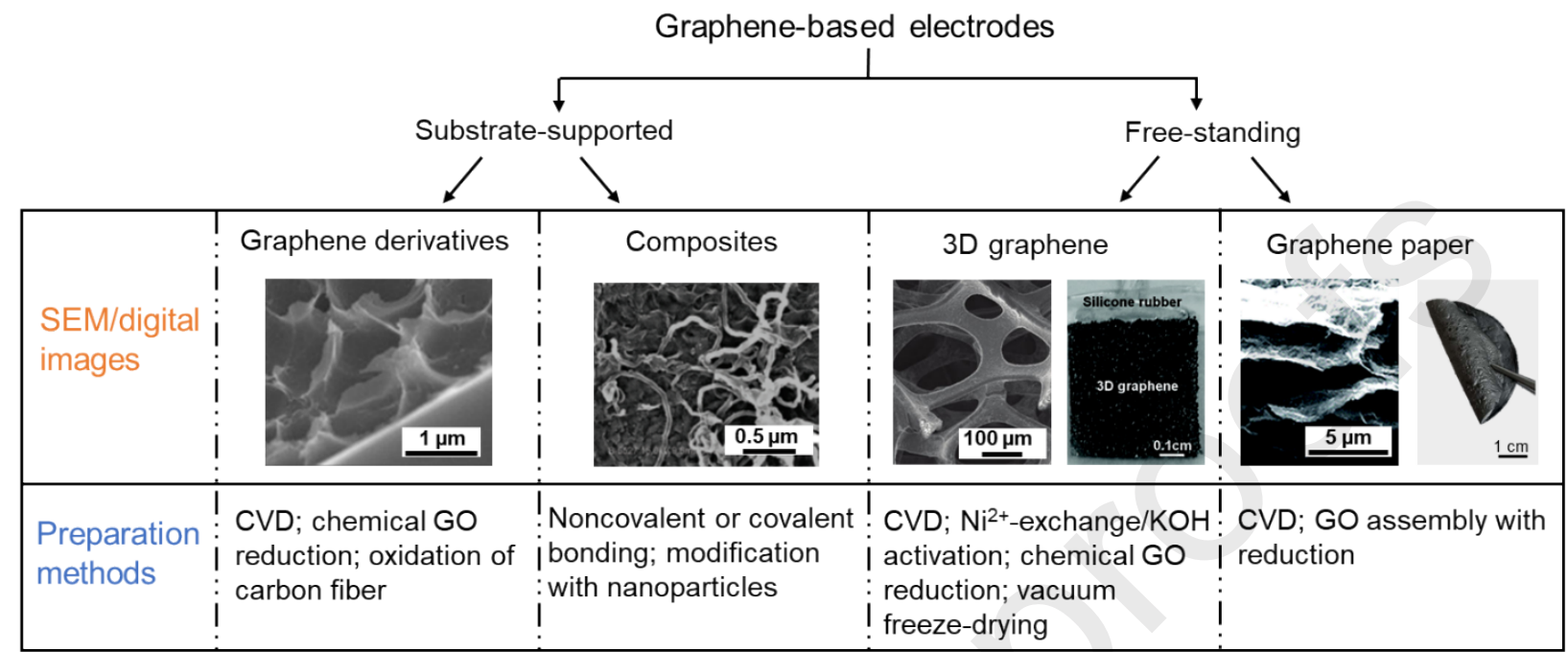

Fig. 2. Fabrication routes for graphene-based electrodes, including graphene derivative and graphene composites modified electrodes as well as free-standing graphene electrodes. Representative scanning electron microscopy (SEM) images (left to right: graphene nanosheets on carbon fibers [62] of carbon papers, graphene/multi-walled CNT (MWCNT) [63], 3D graphene foam [64], and graphene paper [65]). Preparation methods are also summarized. Reprinted with permission from ref. [62-65]. Copyright 2016 John Wiley and Sons; Copyright 2011, 2012 American Chemical Society; Copyright 2019 Royal Society of Chemistry.

\subsection{Graphene derivatives}

Pristine graphene has not been widely exploited as bioelectrode materials due to the lack of functional groups such as oxygenated groups to anchor enzymes [66]. RGO is a graphene derivative with residual oxygenated species on the graphene sheets, which is suitable for construction of enzymatic bioelectrodes [67]. For example, Zhou et al. modified glassy carbon electrodes (GCEs) by drop-casting chemically produced RGO followed by the attachment of GOx [68]. The resulting bioelectrode showed a good biosensing performance for the detection of glucose compared with graphite/GCE-based bioelectrodes. This suggests that the high density of edge-plane like defects on RGO may provide favorable sites to accelerate the reduction of $\mathrm{H}_{2} \mathrm{O}_{2}$ generated on the electrode surface. Unnikrishnan et al. prepared a similar GOx/RGO-based bioelectrode via a one-step process, demonstrating that RGO enabled high stability of GOx and thus a stable response (81\% retention of its initial response after 50 days' storage) [69]. However, aggregation of RGO could result in a decrease of surface area, leading to low enzyme loading and 
electrocatalytic current. It has been reported that a larger amount of laccase can be wired onto anthraquinone-modified RGO/MWCNT $\left(0.77 \mathrm{nmol} \mathrm{cm}^{-2}\right)$ than to the comparable aggregated RGO-based matrix $\left(0.42 \mathrm{nmol} \mathrm{cm}^{-2}\right.$ for anthraquinone-modified RGO and $0.58 \mathrm{nmol} \mathrm{cm}^{-2}$ for MWCNT/RGO) [70]. This implies that modification of RGO sheets with functional groups can prevent aggregation and therefore preserve high surface area for enzyme immobilization with MWCNT, as well as ensure specific adsorption of enzyme with functional groups [70, 71]. Modifications of GO derivatives will be detailed in the section 2.2.

Elemental doping is a versatile method to tune the electronic structure of graphene. GO and RGO can be regarded as a kind of O-doped graphene. Recent attempts to tailor the electronic properties of graphene include doping heteroatoms such as $\mathrm{N}$ [72, 73], P [74], B [75, 76], S [77], and F [78, 79]. Among these, nitrogen-doped graphene (NG) has been widely studied [72, 73, 80, 81]. Compared to graphene and RGO, NG exhibits much better electrocatalytic activity [82] because of a relatively high positive partial charge density on carbon atoms adjacent to the N-doping sites [83, 84], allowing enhanced electrical conductivity [85] and ET efficiency [80]. A NG modified gold electrode has been used to immobilize formate dehydrogenase (FoDH), showing a $500 \mathrm{mV}$ decrease in the oxidation overpotential of reduced nicotinamide adenine dinucleotide (NADH) compared to an undoped graphene electrode [72]. The regeneration of the $\mathrm{NAD}^{+}$cofactor was thus accelerated, leading to more facile formate oxidation process with an onset potential of ca. $-0.25 \mathrm{~V}$ vs. SCE. In addition, a membrane-less glucose/ $\mathrm{O}_{2}$ EBFC with a NG modified GOx based bioanode, mediated by a ferrocene-based polymer, showed an enhanced power output $\left(85.91 \mu \mathrm{W} \mathrm{cm}{ }^{-2}\right)$ over a similar RGO based $\operatorname{EBFC}\left(59.45 \mu \mathrm{W} \mathrm{cm}^{-2}\right)[73]$.

P- and B- doped graphenes as promising electrode materials for supercapacitors [75], batteries [76], and electrocatalysis $[74,86]$ have been reported, but are rarely applied in bioelectrochemistry. Sand F-doped graphenes have been studied for biomolecular sensing, and are promising graphene derivatives for bioelectrochemical applications [77, 78, 87]. A type of S-doped graphene, with abundant micro- and meso-pores, showed activity towards dopamine redox chemistry with high

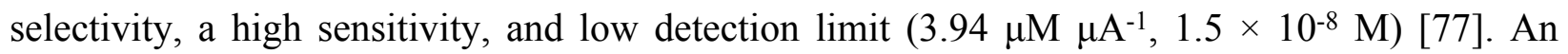
electrochemical F-doped RGO/GCE sensor for histamine showed, for example, a detection limit of $7 \mathrm{nM}$, because the F-atoms provided highly active catalytic sites and fast ET [78]. The electrocatalytic performance of controllably F-doped graphene for NADH oxidation has also been 
investigated, with a decrease in the overpotential of NADH oxidation by $0.25 \mathrm{~V}$ in comparison to a bare GCE. This could be attributed to the higher conductivity of low-fluorinated graphene [87]. $\mathrm{O}$ and $\mathrm{N}$ doped graphenes are the most studied graphene derivatives for the fabrication of graphene-based electrodes in bioelectrochemistry. The main reason could be that these two graphene derivatives can be obtained easily by relatively mild chemical methods. To further explore the potential of electrodes based on graphene derivatives in EBFCs applications, facile and controllable methods of synthesizing doped graphenes are needed.

\subsection{Graphene composites}

Most bioelectrochemical applications of graphene involve functionalized graphene composites, where graphene is functionalized with hydrophilic/hydrophobic or positively/negatively charged groups such as hydroxyl [58], anthraquinone [70], amino [57] and carboxylic surface groups [88].

The formation of functional bonds on graphene layers alters their physical and chemical properties, and precise control over the functionalization processes is therefore required. These functional groups on graphene are particularly important for the attachment of enzymes, affecting the reproducibility and performance of the prepared bioelectrodes.

Covalent bonding and noncovalent interactions are two ways to functionalize graphene. Organic covalent functionalization reactions of graphene include two general routes: (a) transformation of $\mathrm{sp}^{2}$ carbon of pristine graphene to $\mathrm{sp}^{3}$ hybridization with free radicals or dienophiles, and (b) formation of covalent bonds between organic functional groups and the oxygenated groups of GO [89]. Specifically, graphene can be grafted with organic groups using diazonium salts, nitrophenyls, peroxides and hydroxylated aryl groups etc. [41, 88, 90] Bari and co-workers functionalized RGO with two different diazonium molecules bearing either negatively or positively charged groups, preparing DET-type enzymatic electrodes by covalently anchoring laccase and BOx, respectively,. A high catalytic current density plateau $\left(1.0 \mathrm{~mA} \mathrm{~cm}^{-2}\right.$ for laccase and $0.4 \mathrm{~mA} \mathrm{~cm}^{-2}$ for BOx at a rotating disc electrode with a rotating speed of $1500 \mathrm{rpm}$ ) were obtained [88]. Covalent functionalization changed the properties of graphene dramatically. For example, graphene sheets treated with diazonium salts showed a decrease in conductivity with increasing grafting density [91]. Graphene derivatives such as GO and RGO with considerable amounts of oxygenated groups can be grafted to polymer chains using reactive species such as hydroxyl and amine groups. Most of these polymers, e.g. poly(ethylene glycol) (PEG) [92], polylysine (PLL) [93], polyethylenimine 
(PEI) [57], polyallylamine (PAA) [94] and poly(vinyl alcohol) (PVA)[95], are biocompatible and can be used to immobilize proteins. As an example, a PLL/RGO composite with immobilized horseradish peroxidase was used to construct a $\mathrm{H}_{2} \mathrm{O}_{2}$ biosensor exhibiting 2.7-fold higher reduction currents over the control bioelectrode without the utilisation of RGO (at -0.3 V vs. Ag/AgCl) [93]. These composites show synergetic properties: the polymeric part leads to high dispersion in a certain solvent, while graphene offers the electrical conductivity and reinforcement of the mechanical properties.

Noncovalent functionalization includes polymer wrapping [57, 96, 97], adsorption of surfactants such as sodium and lithium dodecyl sulfate [98], direct interactions with nanomaterials such as carbon nanofibers and CNTs $[14,99,100]$ or with small aromatic molecules [65]. Interactions between these modifiers and graphene are usually non-covalent interactions such as $\pi$ - $\pi$, van der Waals, hydrophobic interactions, and electrostatic forces. Various noncovalent modifiers such as chitosan [101], polyaniline (PANI) [94], methylene green (MG) [102, 103], gold nanoparticles (AuNPs) [81, 104] and CNTs [14, 100] etc. have also been used to modify graphene [41, 89]. Depending on the nature of the modifier, noncovalent functionalization can significantly change the dispersibility, conductivity and other properties of graphene. For instance, the use of chitosan ensured the formation of homogeneous graphene suspensions [101] and biocompatibility for enzyme immobilization [105]. Wang and co-workers functionalized graphene with a water-soluble aromatic electroactive dye, MG, and MWCNT through layer-by-layer chemistry (Fig. 2 and Fig. 3) [63]. The resulting nanostructures with MG onto a graphene/MWCNT-based GCE showed lower charge-transfer resistance and better electrocatalytic activities toward NADH oxidation than that of pristine graphene. Such composite structures are therefore suitable for immobilizing NAD ${ }^{+}$ dependent glucose dehydrogenase (GDH) [63]. Other composites containing graphene sheets within a polymer (e.g. poly(3,4-ethylenedioxythiophene) (PEDOT)) or AuNPs dispersed onto graphene showed improved surface area compared to graphene sheets $[104,106]$. Covalently or noncovalently modification of graphene is thus efficient to introduce functional groups on graphene sheets, rendering the resulting composites biocompatible, dispersible, and electrochemically active. These properties are essential to achieve high enzyme loading, proper enzyme orientation and fast interfacial rates of ET on graphene-based electrodes. 


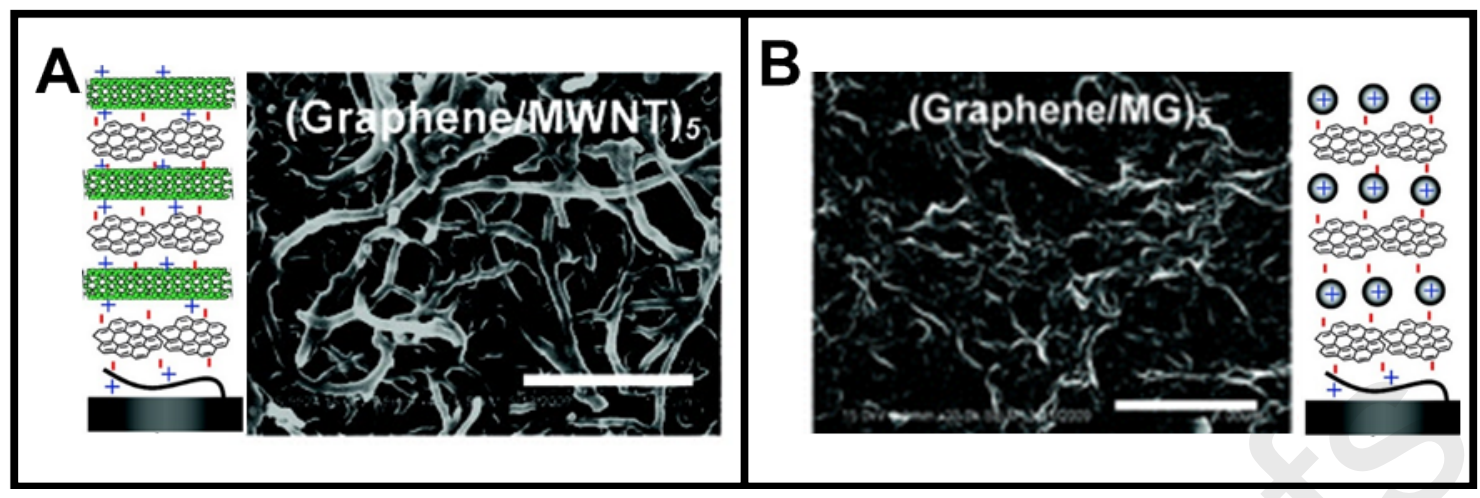

Fig. 3. Schematic illustration of the formation of electrochemically functional (A) (graphene/SWCNT) $)_{5}$ and (B) (graphene/MG) $)_{\mathrm{n}}$ based nanostructures through a layer-by-layer method and corresponding SEM images. 5 represents the number of graphene layer and the scale bar is $1 \mu \mathrm{m}$. MG: methylene green. Reprinted with permission from ref. [63] with modification. Copyright 2011 American Chemical Society.

\subsection{Free-standing graphene}

Bulk electrodes (e.g. GCE, graphite and Au electrodes) are usually used to support graphene and graphene composites for enzyme immobilization. Alternatively, free-standing graphene-based electrodes have been reported widely $[65,100,107]$. Such architectures have been used for enzyme immobilization exploiting the graphene material mechanical strength, as well as the chemical and thermal stability of graphene. Graphene paper is thus one of the most promising free-standing electrode designs for practical applications due to its high flexibility, stability and easy fabrication. Shen et al. engineered a flexible graphene paper via a low-cost solution-processing procedure, (Fig. 2), with the adsorbed enzymes exhibiting excellent mechanical performance, where the catalytic performance of the flexible bioelectrode is little dependent on the degree of mechanical bending $[65,107]$. In addition, 3D graphene platelets and graphene gels were reported recently. For example, Campbell et al. fabricated a free-standing 3D graphene/single-walled CNT (SWCNT) co-gel for a BOx bioelectrode [100]. The co-gel electrode had a large surface area $\left(\sim 800 \mathrm{~m}^{2} \mathrm{~g}^{-1}\right)$ ensuring high enzyme loading, and high porosity for substrate diffusion, while maintaining a moderate conductivity $\left(\sim 0.2 \mathrm{~S} \mathrm{~cm}^{-1}\right)$. Another type of free-standing graphene based electrode is the CVD-derived 3D graphene foam comprising continuous conductive networks, with a large surface area $\left(670 \mathrm{~m}^{2} \mathrm{~g}^{-1}\right)$ for abundant laccase loading (Fig. 2) [14, 64]. 


\section{Features of graphene for bioelectrochemical applications}

Graphene-based electrode materials have excellent features for a range of applications including energy storage and conversion [107], sensing [69], and bioremediation [108]. High electronic conductivity and mechanical strength, both hallmarks of graphene, are essential electrode material requirements. Under ambient conditions, the charge mobility in graphene can reach up to 15000 $\mathrm{cm}^{2} \mathrm{~V}^{-1} \mathrm{~s}^{-1}, 10$-fold of that in silicon [41]. In addition, the electronic conductivity of graphene is almost 60 times higher than that of SWCNTs [109] with a similar mechanical hardness (Young's modulus around $0.98 \mathrm{TPa}$ ) [110]. An early attempt to employ silica sol-gel immobilized graphene sheets/enzyme composite electrodes for EBFCs application was reported in 2010 [111], demonstrating that the catalytic efficiency of graphene based GOx anodes was twice those of SWCNT based GOx ones (Fig. 4A). As a result, the performance of graphene based EBFC similarly doubled (Fig. 4B). With the high optical transparency ( 97\%) and a wide electrochemical window, graphene films are regarded as potential candidates for replacement of the commonly used ITO-covered transparent electrodes in spectro-electrochemistry $[112,113]$.

In contrast to other carbon-based nanomaterials, graphene, consisting of 2D structures, has attracted considerable attention due to its unique layered structure. Monolayer graphene films can be very thin (ranging from 0.34 to $1.6 \mathrm{~nm}$ ) [114]. The remarkable mechanical flexibility and lightness are furthermore key for sensing or wearable bioelectronics applications [39]. RGO, synthesized via a chemical reduction route, resembles crumpled silk due to interactions between the thin layers (Fig. 4C) [112]. The resulting RGO modified electrode showed an electrocatalytic peak for NADH oxidation with a $330 \mathrm{mV}$ peak potential decrease compared to bare GCEs [112]. Furthermore, a graphene paper as a carrier for enzymes (i.e., GDH and BOx) has been used to fabricate EBFCs (Fig. 4D). The resulting glucose/oxygen EBFC displayed a power output up to 4 $\mu \mathrm{W} \mathrm{cm} \mathrm{cm}^{-2}$ (OCV of $0.665 \mathrm{~V}$ ) (Fig. 4E), which could withstand bending up to $180^{\circ}$ without obvious changes in power output due to the exceptional mechanical flexibility of graphene paper (Fig. 4F). This kind of flexible graphene based EBFC holds great promise for driving low power biomedical and bioanalytical microelectronics in particular for wearable applications [65]. 


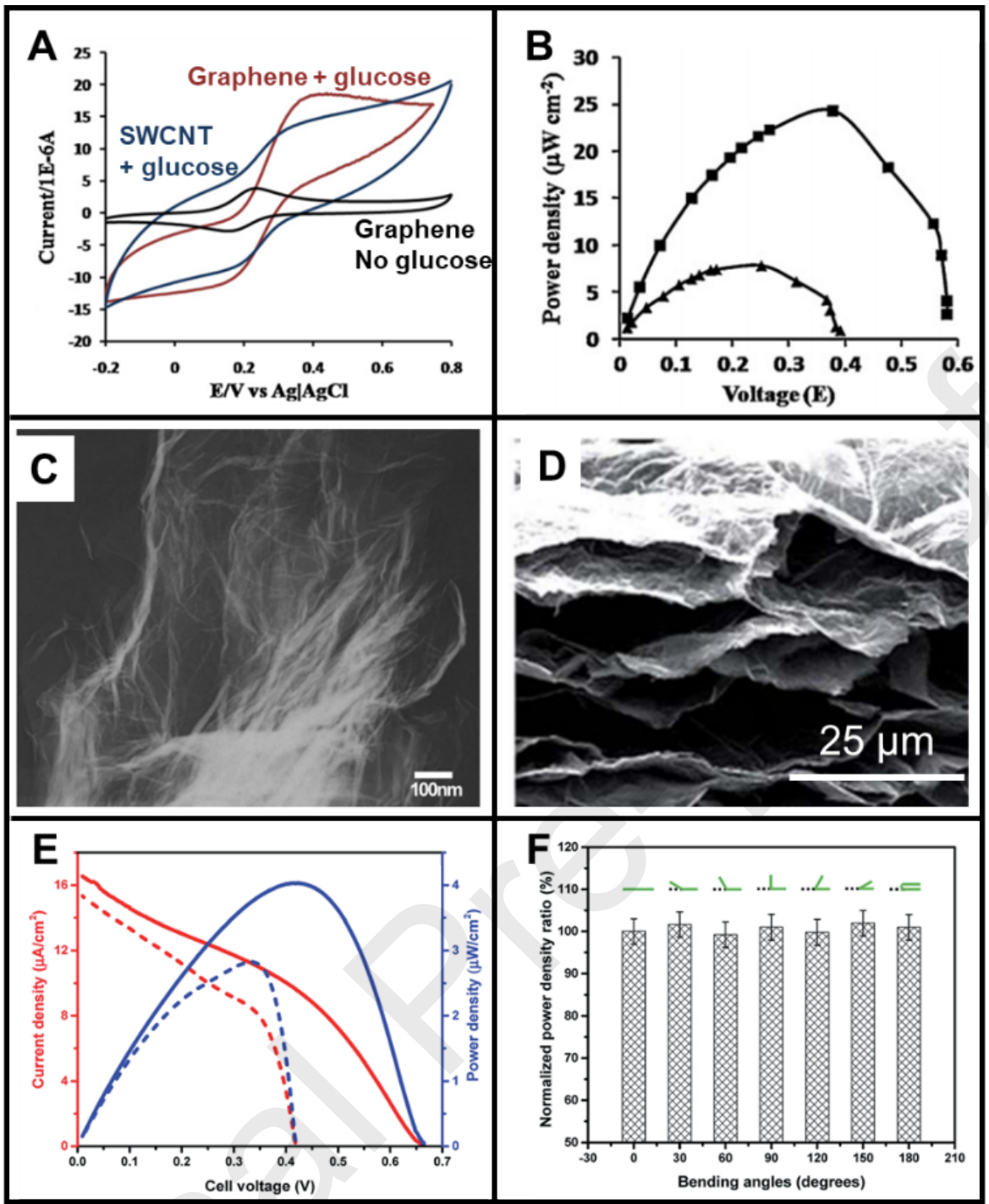

Fig. 4. (A) Cyclic voltammograms of graphene or SWCNT based anode in $100 \mathrm{mM}$ glucose solution and graphene based anode in PBS (PH 7.4) without glucose (scan rate: $500 \mathrm{mV} \mathrm{s}^{-1}$ ). The redox wave originates from the mediator ferrocenemethanol in PBS [111]. (B) Power density profiles for ( $\square$ ) graphene based EBFC and ( $\boldsymbol{\Delta})$ SWCNT based EBFC in $100 \mathrm{mM}$ glucose solution [111]. (C) Transmission electron microscopy (TEM) image of reduced graphene sheet [112]. (D) Cross-section SEM image of the layered assembly of graphene papers [65]. (E) Polarization (red) and power curves (blue) obtained from graphene paper supported GDH bioanode and BOx biocathode in air-saturated buffer containing $6.4 \mathrm{mM}$ glucose. Solid and dashed curves for pure PBS and blood-mimicking buffer, respectively. (F) Power density ratio of the EBFCs after bending to various angles [65]. Reprinted with permission from ref. [65, 111, 112] with modification. Copyright 2010 Elsevier; Copyright 2009 John Wiley and Sons; Copyright 2019 Royal Society of Chemistry.

Graphene-based aerogels constructed by the assembly of the individual graphene sheets display high porosity (i.e. low weight and high surface area) and high performance in both strength and electrical conductivity $[115,116]$. Surface areas for aerogel fibers measured by the Brunauer, 
Emmett and Teller (BET) technique was reported to be $884 \mathrm{~m}^{2} \mathrm{~g}^{-1}$ [116], which is higher than for CNTs $\left(512\right.$ to $\left.790 \mathrm{~m}^{2} \mathrm{~g}^{-1}\right)[117,118]$. Furthermore, Qian et al. prepared aerogels with a weight density as low as $3.2 \mathrm{mg} \mathrm{cm}^{-3}$ and a surface area as high as $1019 \mathrm{~m}^{2} \mathrm{~g}^{-1}$ [115]. A 3D NG aerogel (3D-NGA) incorporated with dopamine can serve as a highly efficient electrocatalyst for $\mathrm{H}_{2} \mathrm{O}_{2}$ reduction (Fig. 5) [119], exhibiting a detection limit of $0.05 \mathrm{mM}$ and a linear detection range up to $35 \mathrm{mM}$. In addition, a GOx biosensor was developed based on a graphene aerogel/AuNPs (GA/AuNPs) hybrid material through a simple hydrothermal route [120]. The porous structure of the GA/GNs hybrid enabled a platform for GOx immobilization. The operation of this bioelectrode was demonstrated for glucose sensing, relying on reducing $\mathrm{H}_{2} \mathrm{O}_{2}$ at $-0.4 \mathrm{~V}$. with a sensitivity of $258 \mu \mathrm{A} \mathrm{mM}^{-1} \mathrm{~cm}^{-2}$ in a linear range from 50 to $450 \mu \mathrm{M}$, and a detection limit of $0.6 \mu \mathrm{M}$.

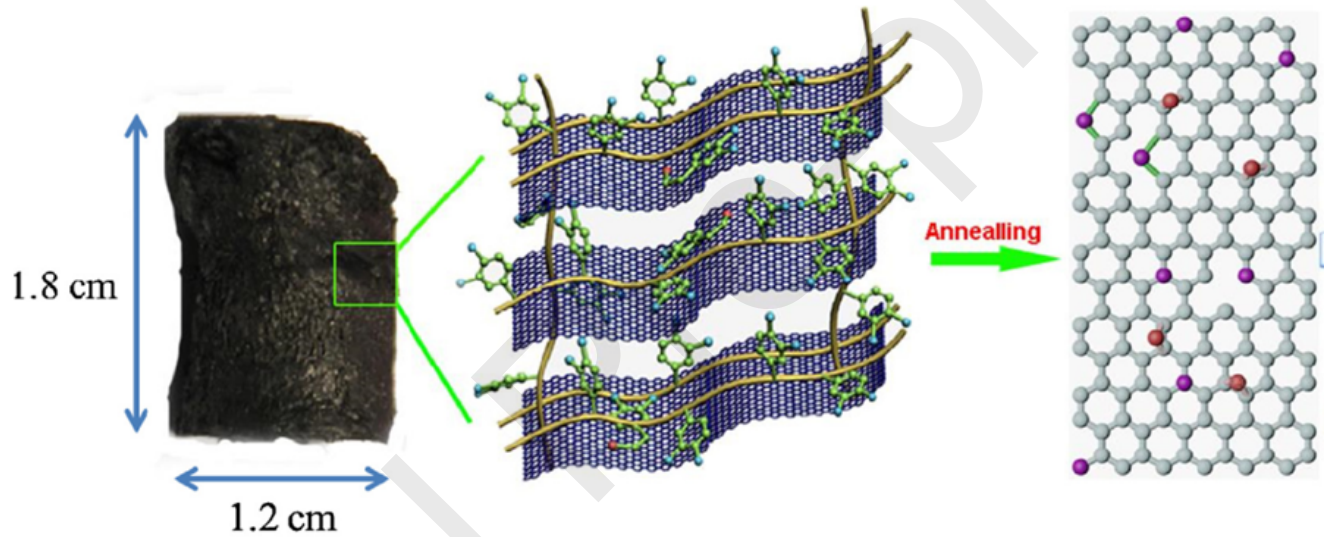

Fig. 5. Digital photo of 3D-NGA and schematic illustration of its preparation [119]. To construct an electrode, the 3D NGA was cut into pieces $(1 \mathrm{~cm} \times 0.5 \mathrm{~cm}, 0.3 \mathrm{~mm}$ thickness $)$. The pieces were then fixed onto a glass slide, and an electrical lead made by copper paste and copper wire insulated with silicone rubber. Reprinted with permission from ref. [119]. Copyright 2016 Elsevier.

\section{Graphene based enzymatic biofuel cells}

Due to the favorable properties noted, the application of graphene in EBFCs offers the potential for improved power output and enhanced operational lifetime. Reports on graphene based EBFCs in the last five years are summarized in Table 1 and Table 2 , showing that this potential is currently being realized. The performance of EBFC is evaluated in terms of maximum power density $\left(\mathrm{P}_{\max }\right)$, OCV, and stability $[15,57,65] . \mathrm{P}_{\max }$ is typically normalized to the geometric electrode area and the mass or volume of the cell [15]. Stability is not effectively measured by following OCV over time [15], as revealed by recent understanding on supercapacitor/EBFC hybrid devices. Instead, evaluation of power output over time provides a better picture of device stability. Most graphene- 
based EBFCs were constructed similarly to CNT-based EBFCs, which do not, however, exploit the full potential of graphene-based devices. Probably due to lack of precise control over the graphene architecture, only a small number of the reported graphene-based EBFCs exceed a $\mathrm{P}_{\max }$ of $1.0 \mathrm{~mW} \mathrm{~cm}^{-2}$ [15]. One example was a membrane-less and $\mathrm{NG}$ based formic acid $/ \mathrm{O}_{2} \mathrm{EBFC}$ that delivered a $\mathrm{P}_{\max }$ of $1.96 \pm 0.13 \mathrm{~mW} \mathrm{~cm}^{-2}$ and an OCV of $0.95 \pm 0.05 \mathrm{~V}$. Effective recycling of $\mathrm{NAD}^{+} / \mathrm{NADH}$ cofactor was achieved at a NG/AuNPs/FoDH bioanode, where NG played the key role in decreasing the NADH oxidation overpotential [72]. Evaluation of graphene-based bioanodes and biocathodes for EBFCs is provided in the following sections. 
Table 1. Summarization of graphene based full EBFCs reported in literature.

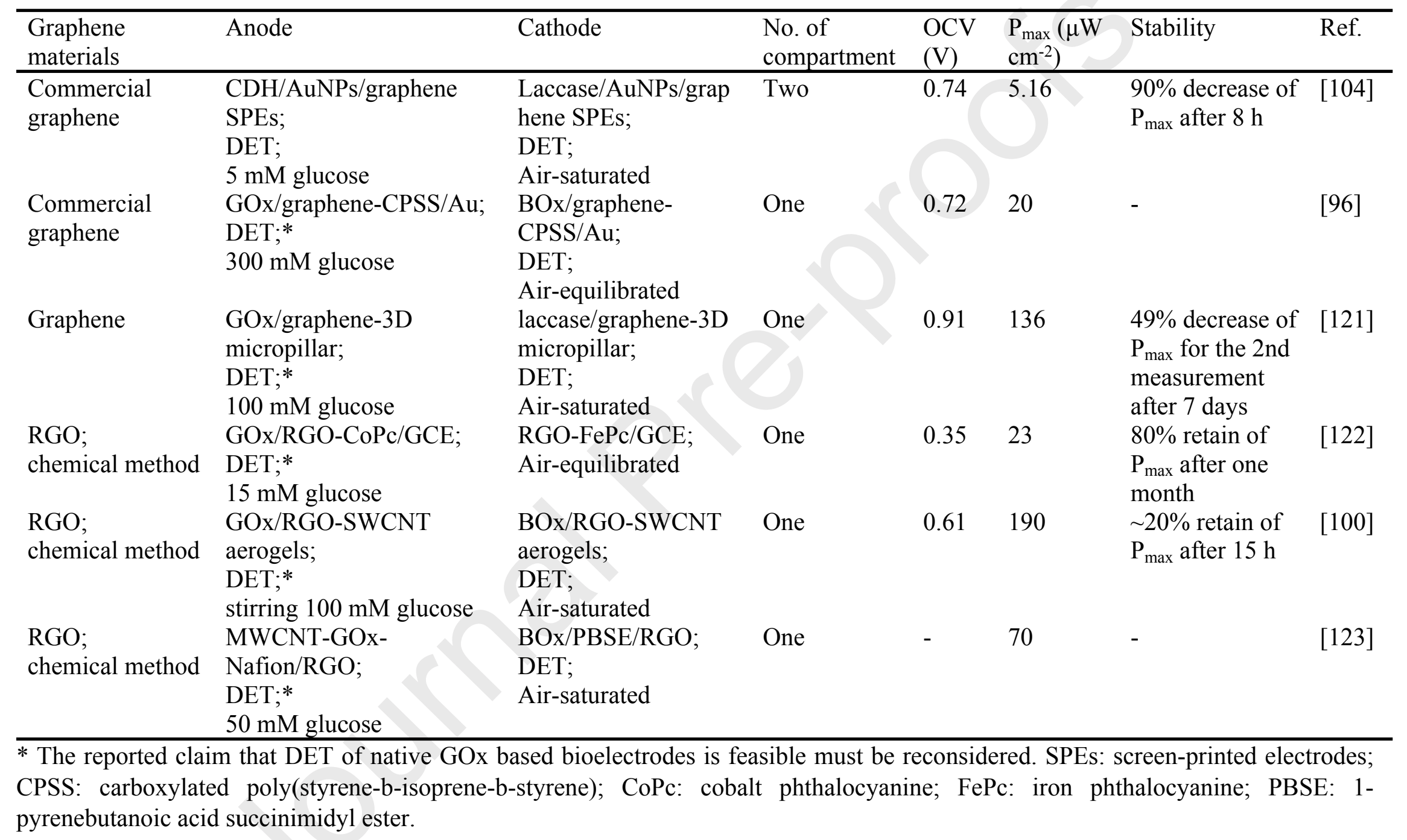


Table 1. Continued.

\begin{tabular}{|c|c|c|c|c|c|c|c|}
\hline Graphene materials & Anode & Cathode & $\begin{array}{l}\text { No. of } \\
\text { compartment }\end{array}$ & $\begin{array}{l}\mathrm{OCV} \\
(\mathrm{V})\end{array}$ & $\begin{array}{l}\mathrm{P}_{\max }(\mu \mathrm{W} \\
\left.\mathrm{cm}^{-2}\right)\end{array}$ & Stability & Ref. \\
\hline $\begin{array}{l}\text { Graphene flakes; } \\
\text { oxidation of carbon } \\
\text { fiber }\end{array}$ & $\begin{array}{l}\mathrm{GDH} / \mathrm{SiO}_{2} \\
\mathrm{NPs} / \mathrm{PEI} / \mathrm{MB} / \text { graphene } \\
\mathrm{CP} ; \\
\mathrm{MET} ; 0.02 \mathrm{mM} \mathrm{NAD}^{+} \\
5 \mathrm{mM} \text { glucose; (human } \\
\text { serum solution) }\end{array}$ & $\begin{array}{l}\mathrm{GOx} / \mathrm{SiO}_{2} \\
\mathrm{NPs} / \text { hemin/graphene } \\
\mathrm{CP} ; \\
\mathrm{DET} \text {; } \\
\mathrm{O}_{2} \text {-equilibrated; (air- } \\
\text { equilibrated) }\end{array}$ & One & $\begin{array}{l}0.50 \\
(0.53)\end{array}$ & $18 ;(4)$ & $\begin{array}{l}-;(\text { decreased } \\
\text { by }>15 \% \\
\text { after } 12 \mathrm{~h})\end{array}$ & [124] \\
\hline $\begin{array}{l}\text { Graphene flakes; } \\
\text { oxidation of carbon } \\
\text { fiber }\end{array}$ & $\begin{array}{l}\text { PQQ-GDH- } \\
\text { CaM/PBSE/graphene } \\
\mathrm{CP} \\
\text { DET; } \\
20 \mathrm{mM} \text { glucose }\end{array}$ & $\begin{array}{l}\text { GOx/hemin/graphene } \\
\mathrm{CP} \text {; } \\
\text { DET; } \\
\text { Air-equilibrated }\end{array}$ & One & $\sim 0.50$ & $\sim 70$ & - & [126] \\
\hline $\begin{array}{l}\text { Graphene flakes; } \\
\text { oxidation of carbon } \\
\text { fiber }\end{array}$ & $\begin{array}{l}\text { PQQ- } \\
\text { GDH/PBSE/graphene } \\
\mathrm{CP} \\
\text { DET; } \\
20 \mathrm{mM} \text { glucose }\end{array}$ & $\begin{array}{l}\text { Laccase/PBSE/graphen } \\
\text { e CP; } \\
\text { DET; } \\
\text { Air-equilibrated }\end{array}$ & One & 0.41 & 5.5 & - & [127] \\
\hline
\end{tabular}

$\mathrm{SiO}_{2}$ NPs: $\mathrm{SiO}_{2}$ nanoparticles; MB: Meldola's blue; $\mathrm{CP}$ : carbon paper; LDH: lactate dehydrogenase; LOx: lactate oxidase; PQQ: pyrroloquinolinequinone; CaM: calmodulin chimer. 
Table 1. Continued.

\begin{tabular}{|c|c|c|c|c|c|c|c|}
\hline Graphene materials & Anode & Cathode & $\begin{array}{l}\text { No. of } \\
\text { compartment }\end{array}$ & $\begin{array}{l}\mathrm{OCV} \\
(\mathrm{V})\end{array}$ & $\begin{array}{l}P_{\max }(\mu \mathrm{W} \\
\left.\mathrm{cm}^{-2}\right)\end{array}$ & Stability & Ref. \\
\hline $\begin{array}{l}\text { NG; } \\
\text { chemical method }\end{array}$ & $\begin{array}{l}\text { FoDH/AuNPs/NG/Au; } \\
\text { MET; } 5 \text { mM NAD }{ }^{+} \\
50 \mathrm{mM} \text { formic acid }\end{array}$ & $\begin{array}{l}\text { Laccase/AuNPs/NG/ } \\
\mathrm{Au} ; \\
\mathrm{MET}, 0.5 \mathrm{mM} \\
\text { ABTS; } \\
\mathrm{O}_{2} \text {-equilibrated }\end{array}$ & One & 0.95 & 1960 & - & {$[72]$} \\
\hline $\begin{array}{l}\text { Graphene paper; } \\
\text { GO assembly with } \\
\text { reduction }\end{array}$ & $\begin{array}{l}\text { PQQ- } \\
\text { GDH/MB/graphene } \\
\text { paper; } \\
\text { MET; } \\
6.4 \mathrm{mM} \text { glucose }\end{array}$ & $\begin{array}{l}\text { BOx/graphene paper; } \\
\text { DET; } \\
\text { Air-equilibrated }\end{array}$ & One & 0.67 & 4.0 & $\begin{array}{l}35 \% \text { and } 55 \% \\
\text { retain after } 100 \\
\text { min in a static } \\
\text { or stirring } \\
\text { solution, } \\
\text { respectively }\end{array}$ & {$[65]$} \\
\hline $\begin{array}{l}\text { Graphene paper; } \\
\text { GO assembly with } \\
\text { reduction }\end{array}$ & $\begin{array}{l}\text { PQQ-GDH/cytochrome } \\
\text { c/graphene paper; } \\
\text { MET; } \\
3 \text { mM glucose }\end{array}$ & $\begin{array}{l}\text { BOx/cytochrome } \\
\text { c/graphene paper; } \\
\text { DET; } \\
\text { Air-equilibrated }\end{array}$ & One & 0.38 & 0.29 & - & {$[107]$} \\
\hline $\begin{array}{l}\text { 3D graphene; } \\
\mathrm{Ni}^{2+} \text {-exchange/ } \\
\mathrm{KOH} \text { activation }\end{array}$ & $\begin{array}{l}\text { Nafion/GOx/Fc/3D- } \\
\text { graphene/GCE; } \\
\text { MET; } \\
10 \text { mM glucose }\end{array}$ & $\begin{array}{l}\text { Nafion/laccase/3D- } \\
\text { graphene-PTCA- } \\
\text { DA/GCE; } \\
\text { MET; } \\
\mathrm{O}_{2} \text {-equilibrated }\end{array}$ & One & 0.40 & 112 & $\begin{array}{l}\sim 84 \% \text { retain of } \\
\text { initial j after } 72- \\
\mathrm{h} \text { discharging }\end{array}$ & {$[56]$} \\
\hline
\end{tabular}


Table 2. Summarization of graphene based bioanodes for EBFCs reported in literature.

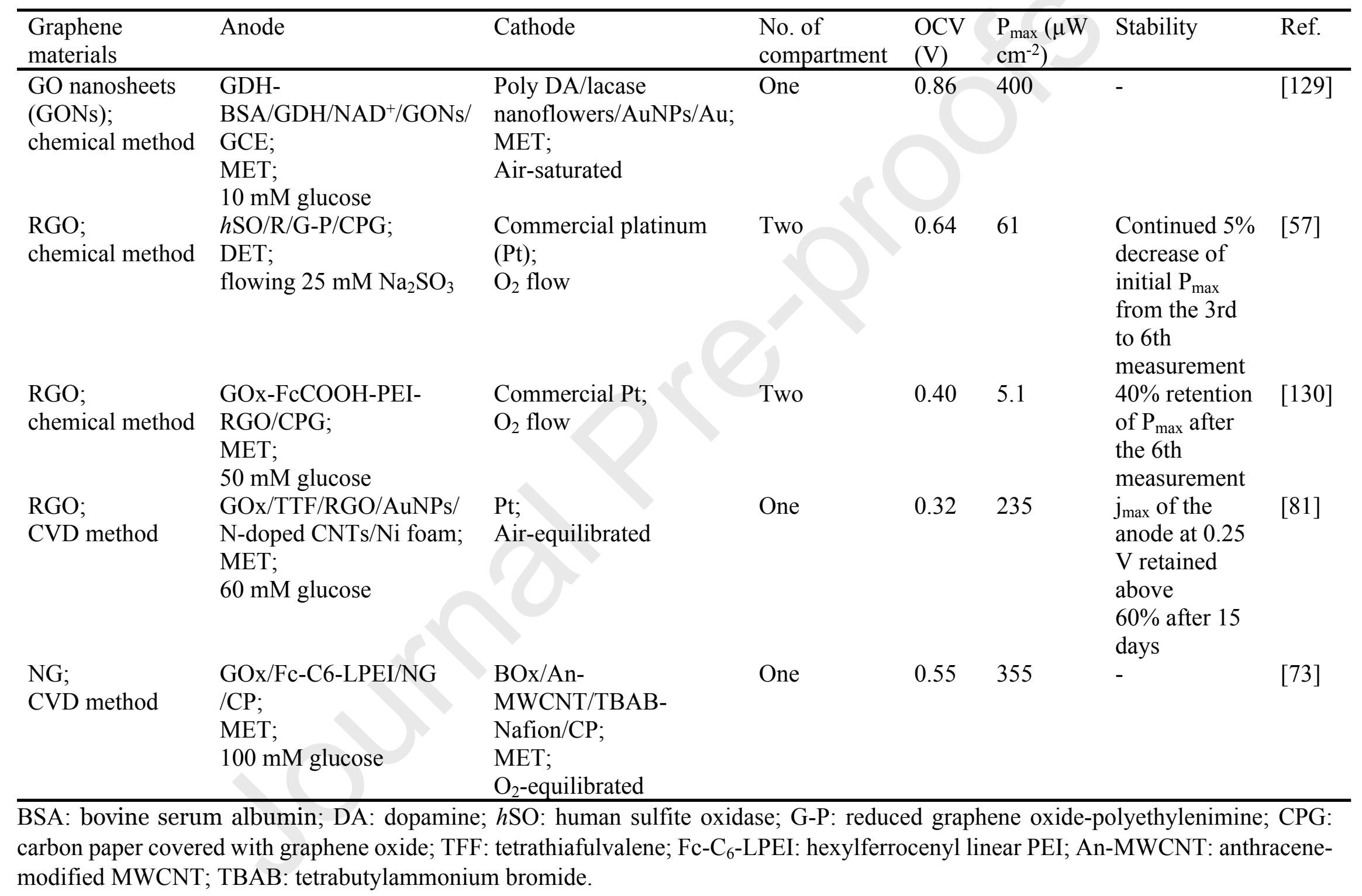




\subsection{Graphene based bioanodes}

A broad range of fuels can be oxidized at bioanodes, including $\mathrm{H}_{2}$, sugars (glucose, lactose, starch etc.), alcohols (methanol, ethanol, glycol etc.). Inorganic salts such as sulfite can also serve as fuels [57]. Glucose, a cheap fuel resource, has been most extensively investigated as the majority of EBFCs studies focus on applications in blood analysis with a certain variable concentration of glucose (typically 2-10 mM for normal blood) [131]. Representative mediated bioelectrocatalytic reactions by flavin adenine dinucleotide (FAD) dependent-GOx are shown schematically in eq. 1-3, where " $M_{\text {red" }}$ " and " $M_{o x}$ " represent the reduced and oxidized form of the mediator, respectively. It should be noted that native GOx cannot undergo DET as the flavin group is too deeply buried in the protein matrix [132]. Various graphene materials have been used in the fabrication of GOx bioanodes for glucose/ $\mathrm{O}_{2}$ EBFCs, including chemically produced 2D graphene sheets [96, 104, 122], graphene papers [65, 107], $\mathrm{NG}$ sheets [73], and 3D graphene [121]. Glucose $/ \mathrm{O}_{2} \mathrm{EBFCs}$ functionalized with 3D graphene showed considerable $P_{\max }$ values, ranging from 112 to $136 \mu \mathrm{W}$ $\mathrm{cm}^{-2}$, Table 1. Furthermore, a commercially available GOx (Amano Enzyme Inc., Japan) shows broader substrate response than most other common bioanode enzymes, and can oxidize many mono-, di-, tri-, and polysaccharides [133]. Such non-selective activity, though being an issue in biosensor applications, can be a great advantage for EBFCs.

Other enzymes such as GDH [65] and CDH [104] have also been used successfully as biocatalysts for the oxidation of glucose at graphene-based bioanodes. Due to the insensitivity to $\mathrm{O}_{2}$, dehydrogenases can operate effectively in a one-compartment cell, where $\mathrm{O}_{2}$ reduction takes place at the biocathode. For example, pyrroloquinoline quinone (PQQ) dependent GDH modified graphene paper showed good electrocatalytic activity in air-saturated electrolytes [65]. We combined the resulting bioanode with a BOx graphene-based cathode into a one-compartment EBFC. The device displayed an acceptable power output in air-saturated phosphate buffer containing $6.4 \mathrm{mM}$ glucose, with an OCV of $0.665 \mathrm{~V}$ and a $\mathrm{P}_{\max }$ of approximately $4 \mu \mathrm{W} \mathrm{cm} \mathrm{cm}^{-2}$.

$$
\begin{aligned}
\mathrm{GOx}(\mathrm{FAD})+\mathrm{C}_{6} \mathrm{H}_{12} \mathrm{O}_{6} & \rightarrow \mathrm{GOx}\left(\mathrm{FADH}_{2}\right)+\mathrm{C}_{6} \mathrm{H}_{10} \mathrm{O}_{6} \\
\mathrm{GOx}\left(\mathrm{FADH}_{2}\right)+\mathrm{M}_{\mathrm{ox}} & \rightarrow \mathrm{GOx}(\mathrm{FAD})+\mathrm{M}_{\mathrm{red}} \\
\mathrm{M}_{\mathrm{re}} & \leftrightarrow \mathrm{M}_{\mathrm{ox}}+2 \mathrm{e}^{-}
\end{aligned}
$$


Although glucose is used as the fuel in most graphene based EBFCs, other fuels need be investigated. Lactate, present at a concentration of 5-60 $\mathrm{mM}$ in sweat [38], has been catalytically oxidized at graphene based bioanodes, enabling development of wearable lactate $/ \mathrm{O}_{2} \mathrm{EBFCs}[125$, 134]. Such EBFCs can be externally located on the skin in contrast to glucose-powered devices that need to be surgically implanted in the body. Koushanpour et al. constructed a graphene-based lactate $/ \mathrm{H}_{2} \mathrm{O}_{2}$ EBFC using a lactate dehydrogenase (LDH) bioanode and a lactate oxidase (LOx)/hemin biocathode (Scheme 2) [125]. An electrode functionalized with graphene nanosheets by in situ electrochemically produced graphene flakes on carbon fibers was reported [125]. The resulting EBFC delivered a $\mathrm{P}_{\max }$ of 380 and $225 \mu \mathrm{W} \mathrm{cm}{ }^{-2}$ when operated in a simulated human sweat (14 mM lactate) and real human sweat, respectively [125]. Sodium sulfite has also been utilized as a biofuel for graphene-based bioanodes [57]. Oxidation of sulfite to sulfate can be catalyzed by human sulfite oxidase ( $h \mathrm{SO})$, which has a Mo centered catalytic site and a built-in heme redox relay. A graphene-coated CP with large 3D porosity was demonstrated as a suitable support for immobilization of $h \mathrm{SO}$ with efficient heterogeneous ET and a saturation catalytic current of $24.4 \mu \mathrm{A} \mathrm{cm}^{-2}$. The $h \mathrm{SO}$ graphene-based bioelectrodes were then exploited as bioanodes in hybrid EBFCs, coupled with a Pt based cathode. The EBFC with OCV of $0.64 \mathrm{~V}$ gave a $\mathrm{P}_{\max }$ of $61 \mu \mathrm{W} \mathrm{cm}{ }^{-2}$, which is 6.6-fold better performance than previously reported sulfite $/ \mathrm{O}_{2} \mathrm{EBFCs}$ using AuNPs $[57,135]$. CPs, used as the $h$ SO bioanode substrate, are typically hydrophobic, making it difficult to allow the enzyme solution to penetrate into the 3D matrix. Ultrasonic pre-treatment of CPs in suspensions of GO can enhance the GO coating by $\pi-\pi$ interactions and therefore result in the improved hydrophilicity due to the presence of GO sheets on carbon fibers of CP [130]. GO pre-treated CP was shown to be a good support for a bioink consisting of GOx and mediator as well as graphene-polymer composites [130], resulting in a glucose/oxygen biofuel cells with a $\mathrm{P}_{\max }$ of $5.1 \mu \mathrm{W} \mathrm{cm}-2$ at $25^{\circ} \mathrm{C}$.

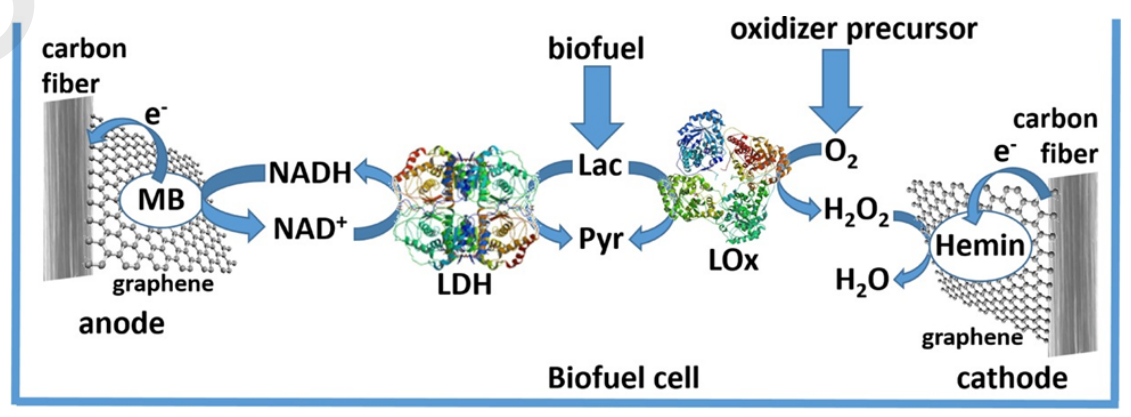

Scheme 2. A scheme of the lactate $/ \mathrm{H}_{2} \mathrm{O}_{2}$ graphene-based biofuel cell. NADH and $\mathrm{H}_{2} \mathrm{O}_{2}$ formed by the 
enzymes are consumed through electrocatalytic reactions by Meldola blue (MB) and hemin, respectively. Reprinted with permission from ref. [125]. Copyright 2017 John Wiley and Sons.

\subsection{Graphene based biocathodes}

The dioxygen reduction reaction (ORR) is the priority for biocathode research since most EBFC applications rely on using $\mathrm{O}_{2}$ as the oxidant. Blue copper enzymes such as laccase and BOx have been widely utilized at biocathodes to catalyze the four-electron reduction of dioxygen to water $[14,136,137]$. The active centers of both laccase and BOx include four $\mathrm{Cu}$ atoms classified as $\mathrm{T} 1$, $\mathrm{T} 2$ and $\mathrm{T} 3$. The CuT1 site near the surface of the protein accepts electrons from electrodes. The electrons are then shifted to the $\mathrm{CuT2} / \mathrm{T} 3$ trinuclear cluster at the inside of the proteins, where dioxygen is reduced efficiently to water. Usually high-potential laccase only produces appreciable catalytic current in acidic solution $(\sim \mathrm{pH} 5.0)$, while BOx can catalyze dioxygen reduction in neutral solutions. The redox potential of BOD CuT1 (490 mV vs. NHE at pH 5.3) is generally lower than that of laccase, so the activity of commercial BOD is lower than that of laccase [138].

The performance of these biocathodes varies when immobilized on different graphene architectures. Graphene sheet composite is the most studied substrate for enzyme immobilization among graphene materials. In EBFC application, laccase undergoing MET on NG-AuNPs $\left(\mathrm{P}_{\max }\right.$ : $\left.1,960 \mu \mathrm{W} \mathrm{cm}{ }^{-2}\right)$ [72] and DET on graphene-3D micropillar composites $\left(\mathrm{P}_{\max }: 136 \mu \mathrm{W} \mathrm{cm}{ }^{-2}\right)$ [121], respectively, have been reported. Most BOx biocathodes used in EBFCs can directly receive electrons from the electrode surface, such as the case where BOx is physically adsorbed on RGOSWCNT aerogels as a biocathode, assembled with a GOx bioanode in an EBFC ( $\mathrm{P}_{\max }: 190 \mu \mathrm{W}$ $\mathrm{cm}^{-2}$ ) [100]. 3D graphene-based electrode is also a promising support for laccase and BOx immobilization due to the high surface area. Recently, laccase was immobilized on 3D graphene networks produced by $\mathrm{Ni}^{2+}$-exchange/KOH activation combination. With the help of an immobilized mediator (dopamine) this biocathode was coupled to a GOx bioanode in a glucose $/ \mathrm{O}_{2}$

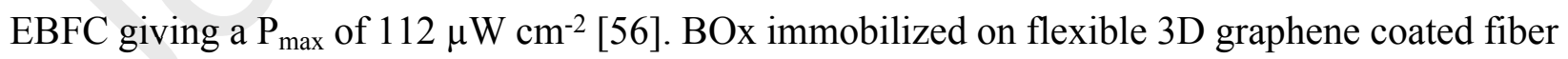
cloth can be applied in a glucose EBFC with a GOx bioanode, resulting in a $P_{\max }$ of $34.4 \mu \mathrm{W} \mathrm{cm}-$ 2 at $0.43 \mathrm{~V}$ [128]. In addition, an electrochemically produced graphene-based laccase biocathode can reach a DET catalytic current density of $1.0 \mathrm{~mA} \mathrm{~cm}^{-2}$ under stirring at $1,500 \mathrm{rpm}$ [88].

In addition to $\mathrm{O}_{2}, \mathrm{H}_{2} \mathrm{O}_{2}$ generated in-situ can be reduced at the biocathode through catalytic reactions [139]. Koushanpour et al. fabricated FAD-dependent oxidases, i.e., GOx [124, 126] and 
LOx [125], on hemin modified graphene CP biocathodes. GOx and LOx produce $\mathrm{H}_{2} \mathrm{O}_{2}$ during the catalysis of the oxidation of glucose and lactate, respectively, in the presence of oxygen. The immobilized hemin can reduce the generated $\mathrm{H}_{2} \mathrm{O}_{2}$ electrocatalytically by accepting the electrons from the CP electrode (Scheme 2). These GOx and LOx immobilized hemin/graphene CP biocathodes can been incorporated in glucose $/ \mathrm{H}_{2} \mathrm{O}_{2}$ or lactate $/ \mathrm{H}_{2} \mathrm{O}_{2}$ EBFCs with a GDH and LDH bioanode, respectively. Although a small number of high-performance graphene-based EBFCs $\left(\mathrm{P}_{\max }>1.0 \mathrm{~mW} \mathrm{~cm}^{-2}\right)$ has been reported, the half-lifetime of the EBFCs ranges from several hours to days. Improvement of the performance of graphene-based bioanodes and biocathodes especially the long-term stability is thus an essential step for development of EBFCs.

\section{Conclusions and perspectives}

Graphene-based materials have been extensively studied for use in EBFCs. A number of graphenebased materials, including GO, RGO and graphene composites with polymers, CNTs and AuNPs etc, can be used for the fabrication of bioelectrodes. The introduction of graphene can improve the lifetime and catalytic efficiency of EBFCs, though the stability and power output of such cells is significantly less than that of conventional FC. In respect of energy generation, robust and porous supporting materials are essential for practical applications. Supporting materials with large porosity must be compatible with both graphene and enzymes. However, the precise control of graphene-based materials synthesis (such as surface functionalization and design of hierarchical structure) and enzymes immobilization on graphene-based electrode surfaces, as well as understanding of the aggregation of graphene flakes leading to a decreased surface area remains as a challenge. The implementation of graphene-based EBFCs in implantable medical devices, although barely reported so far, requires further exploration. Such devices in animal or human bodies might cause inflammatory reaction and blood clotting [15]. As learnt from other carbon nanomaterial based EBFCs, these challenges could be addressed by device encapsulation with dialysis bags [140] and coating by polymers such as chitosan [141] and 2-methacryloyloxyethyl phosphorylcholine [142], to improve the biocompatibility.

The main directions of research in graphene based EBFCs are i) miniaturization aiming at implementation in/on human body and ii) energy generation for portable devices. The following perspectives can be of interest for future investigation: (1) Graphene quantum dots (GQDs) may be a suitable platform considering the easy grafting chemistry due to the presence of carboxylic 
acid moieties at the edges of GQDs, the likely facilitated ET, and large specific surface areas [143]. (2) Lightweight graphene-based electrodes such as graphene hydrogels for bioanode and biocathode fabrications are promising for portable and wearable EBFCs benefiting from their low weight and high flexibility. (3) CVD derived graphene can serve as integrated electrodes of onchip enzymatic devices for miniaturized biosensing or bio-powering [66, 144]. (4) A wide range of fuel molecules such as inorganic molecules or cheap biomass-derived biofuels using new enzymes provides scope for the construction of stable and efficient graphene-based bioanodes and biocathodes as well as other enzymatic bioelectrodes. With recent advances in fabricating sophisticated bioelectrodes as overviewed in the present report, there is significant scope to enable the realization of these perspectives.

\section{Acknowledgements}

Financial support from The Danish Council for Independent Research for the YDUN project (DFF 4093-00297), the Carlsberg foundation (2012_01_0520) and the Russian Science Foundation (project № 17-13-01274) is gratefully acknowledged. This project has received funding from the European Union's Horizon 2020 research and innovation programme under the Marie Skłodowska-Curie grant agreement No. 713683. X.Y. acknowledges support from the China Scholarship Council (CSC, 201806650009).

\section{References}

[1] N. Seselj, C. Engelbrekt, Y. Ding, H.A. Hjuler, J. Ulstrup, J. Zhang, Tailored electron transfer pathways in Aucore/Ptshell-graphene nanocatalysts for fuel cells, Adv. Energy Mater. 8(13) (2018) 1702609.

[2] N. Seselj, C. Engelbrekt, J. Zhang, Graphene-supported platinum catalysts for fuel cells, Sci. Bull. 60(9) (2015) 864-876.

[3] M. Ünlü, J. Zhou, P.A. Kohl, Hybrid polymer electrolyte fuel cells: alkaline electrodes with proton conducting membrane, Angew. Chem. Int. Edit. 49(7) (2010) 1299-1301.

[4] F. Alcaide, P.-L. Cabot, E. Brillas, Fuel cells for chemicals and energy cogeneration, J. Power Sources 153(1) (2006) 47-60.

[5] P. Cai, Y. Li, G. Wang, Z. Wen, Alkaline-acid Zn-H2O fuel cell for the simultaneous generation of hydrogen and electricity, Angew. Chem. 130(15) (2018) 3974-3979.

[6] M.T. Meredith, S.D. Minteer, Inhibition and activation of glucose oxidase bioanodes for use in a self-powered EDTA sensor, Anal. Chem. 83(13) (2011) 5436-41.

[7] G. Slaughter, T. Kulkarni, A self-powered glucose biosensing system, Biosens. Bioelectron. 78 (2016) $45-50$.

[8] L. Halámková, J. Halamek, V. Bocharova, A. Szczupak, L. Alfonta, E. Katz, Implanted biofuel cell operating in a living snail, J. Am. Chem. Soc. 134(11) (2012) 5040-3.

[9] M. Rasmussen, R.E. Ritzmann, I. Lee, A.J. Pollack, D. Scherson, An implantable biofuel cell for a live insect, J. Am. Chem. Soci. 134(3) (2012) 1458-1460.

[10] A. Zebda, S. Cosnier, J.P. Alcaraz, M. Holzinger, A. Le Goff, C. Gondran, F. Boucher, F. Giroud, K. Gorgy, H. Lamraoui, P. Cinquin, Single glucose biofuel cells implanted in rats power electronic devices, Sci. Rep. 3(1) (2013) 1516. 
[11] W. Jia, X. Wang, S. Imani, A.J. Bandodkar, J. Ramírez, P.P. Mercier, J. Wang, Wearable textile biofuel cells for powering electronics, J. Mater. Chem. A 2(43) (2014) 18184-18189.

[12] X. Xiao, T. Siepenkoetter, P.Ó. Conghaile, D. Leech, E. Magner, Nanoporous gold-based biofuel cells on contact lenses, ACS Appl. Mater. Inter. 10(8) (2018) 7107-7116.

[13] A. Ruff, J. Szczesny, N. Marković, F. Conzuelo, S. Zacarias, I.A.C. Pereira, W. Lubitz, W. Schuhmann, A fully protected hydrogenase/polymer-based bioanode for high-performance hydrogen/glucose biofuel cells, Nat. Commun. 9(1) (2018) 3675.

[14] K.P. Prasad, Y. Chen, P. Chen, Three-dimensional graphene-carbon nanotube hybrid for high-performance enzymatic biofuel cells, ACS Appl. Mater. Inter. 6(5) (2014) 3387-93.

[15] X. Xiao, H.-q. Xia, R. Wu, L. Bai, L. Yan, E. Magner, S. Cosnier, E. Lojou, Z. Zhu, A. Liu, Tackling the challenges of enzymatic (bio)fuel cells, Chem. Rev. 119 (2019) 9509-9558.

[16] J. Kim, H. Jia, P. Wang, Challenges in biocatalysis for enzyme-based biofuel cells, Biotechnol. Adv. 24(3) (2006) 296-308.

[17] U. Hanefeld, L. Gardossi, E. Magner, Understanding enzyme immobilisation, Chem. Soc. Rev. 38(2) (2009) 453-468.

[18] M.J. Moehlenbrock, S.D. Minteer, Introduction to the field of enzyme immobilization and stabilization, Methods Mol. Biol. 1504 (2017) 1-7.

[19] E.J. Wright, M. Sosna, S. Bloodworth, J.D. Kilburn, P.N. Bartlett, Design of maleimide-functionalised electrodes for covalent attachment of proteins through free surface cysteine groups, Chem-Eur. J. 20(19) (2014) 5550-5554.

[20] F.A. Al-Lolage, M. Meneghello, S. Ma, R. Ludwig, P.N. Bartlett, A flexible method for the stable, covalent immobilization of enzymes at electrode surfaces, Chemelectrochem 4(6) (2017) 1528-1534.

[21] F.A. Al-Lolage, P.N. Bartlett, S. Gounel, P. Staigre, N. Mano, Site-directed immobilization of bilirubin oxidase for electrocatalytic oxygen reduction, ACS Catal. 9(3) (2019) 2068-2078.

[22] M.J. Moehlenbrock, S.D. Minteer, Extended lifetime biofuel cells, Chem. Soc. Rev. 37(6) (2008) 1188-1196.

[23] C.M. Moore, N.L. Akers, A.D. Hill, Z.C. Johnson, S.D. Minteer, Improving the environment for immobilized dehydrogenase enzymes by modifying nafion with tetraalkylammonium bromides, Biomacromolecules 5(4) (2004) 1241-1247.

[24] K. Szot, W. Nogala, J. Niedziolka-Jönsson, M. Jönsson-Niedziolka, F. Marken, J. Rogalski, C.N. Kirchner, G. Wittstock, M. Opallo, Hydrophilic carbon nanoparticle-laccase thin film electrode for mediatorless dioxygen reduction: SECM activity mapping and application in zinc-dioxygen battery, Electrochim. Acta 54(20) (2009) 46204625 .

[25] A. Heller, Miniature biofuel cells, Phys. Chem. Chem. Phys. 6(2) (2004) 209-216.

[26] X. Xiao, P.Ó. Conghaile, D. Leech, R. Ludwig, E. Magner, An oxygen-independent and membrane-less glucose biobattery/supercapacitor hybrid device, Biosens. Bioelectron. 98 (2017) 421-427.

[27] S. Sotiropoulou, V. Vamvakaki, N.A. Chaniotakis, Stabilization of enzymes in nanoporous materials for biosensor applications, Biosens. Bioelectron. 20(8) (2005) 1674-1679.

[28] X. Xiao, P. Si, E. Magner, An overview of dealloyed nanoporous gold in bioelectrochemistry,

Bioelectrochemistry 109 (2016) 117-126.

[29] X. Xiao, T. Siepenkoetter, R. Whelan, U. Salaj-Kosla, E. Magner, A continuous fluidic bioreactor utilising electrodeposited silica for lipase immobilisation onto nanoporous gold, J. Electroanal. Chem. 812 (2018) 180-185. [30] X. Xiao, P.Ó. Conghaile, D. Leech, R. Ludwig, E. Magner, A symmetric supercapacitor/biofuel cell hybrid device based on enzyme-modified nanoporous gold: An autonomous pulse generator, Biosens. Bioelectron. 90 (2017) 96-102.

[31] A.J. Gross, M. Holzinger, S. Cosnier, Buckypaper bioelectrodes: emerging materials for implantable and wearable biofuel cells, Energy Environ. Sci. 11(7) (2018) 1670-1687.

[32] A.T. Lawal, Graphene-based nano composites and their applications. A review, Biosens. Bioelectron. 141 (2019) 111384.

[33] D. Li, R.B. Kaner, Graphene-based materials, Science 320(5880) (2008) 1170-1171.

[34] M.J. Allen, V.C. Tung, R.B. Kaner, Honeycomb carbon: a review of graphene, Chem. Rev. 110(1) (2010) $132-$ 145 .

[35] J. Filip, J. Tkac, Effective bioelectrocatalysis of bilirubin oxidase on electrochemically reduced graphene oxide, Electrochem. Commun. 49 (2014) 70-74.

[36] H. Wang, F. Teng, L. Zhang, Q. Zhang, H. Zhang, T. Pei, S. Li, L. Xia, Meso-cellular silicate foam modified reduced graphene oxide with sandwich structure for enzymatic immobilization and bioelectrocatalysis, ACS Appl. Mater. Inter. 11(33) (2019) 29522-29535. 
[37] S.M. Mostafavi, 3D graphene biocatalysts for development of enzymatic biofuel cells: a short review, J. Nanoanalysis 2 (2015) 57-62.

[38] Y. Yu, H.Y.Y. Nyein, W. Gao, A. Javey, Flexible electrochemical bioelectronics: the rise of in situ bioanalysis, Adv. Mater. (2019) 1902083.

[39] Y.J. Yun, J. Ju, J.H. Lee, S.-H. Moon, S.-J. Park, Y.H. Kim, W.G. Hong, D.H. Ha, H. Jang, G.H. Lee, H.-M.

Chung, J. Choi, S.W. Nam, S.-H. Lee, Y. Jun, Highly elastic graphene-based electronics toward electronic skin,

Adv. Funct. Mater. 27(33) (2017) 1701513.

[40] J. Filip, J. Tkac, Is graphene worth using in biofuel cells?, Electrochim. Acta 136 (2014) 340-354.

[41] A. Karimi, A. Othman, A. Uzunoglu, L. Stanciu, S. Andreescu, Graphene based enzymatic bioelectrodes and biofuel cells, Nanoscale 7(16) (2015) 6909-6923.

[42] H.-J. Qiu, Y. Guan, P. Luo, Y. Wang, Recent advance in fabricating monolithic 3D porous graphene and their applications in biosensing and biofuel cells, Biosens. Bioelectron. 89 (2017) 85-95.

[43] S. Park, R.S. Ruoff, Chemical methods for the production of graphenes, Nat. Nanotech. 4(4) (2009) 217-224.

[44] Y. Si, E.T. Samulski, Synthesis of water soluble graphene, Nano Lett. 8(6) (2008) 1679-1682.

[45] Y. Xu, H. Bai, G. Lu, C. Li, G. Shi, Flexible graphene films via the filtration of water-soluble noncovalent functionalized graphene sheets, J. Am. Chem. Soc. 130(18) (2008) 5856-5857.

[46] Y. Hernandez, V. Nicolosi, M. Lotya, F.M. Blighe, Z. Sun, S. De, I.T. McGovern, B. Holland, M. Byrne, Y.K. Gun'Ko, J.J. Boland, P. Niraj, G. Duesberg, S. Krishnamurthy, R. Goodhue, J. Hutchison, V. Scardaci, A.C. Ferrari, J.N. Coleman, High-yield production of graphene by liquid-phase exfoliation of graphite, Nat. Nanotech. 3(9) (2008) 563-568.

[47] M.D. Stoller, S. Park, Y. Zhu, J. An, R.S. Ruoff, Graphene-based ultracapacitors, Nano Lett. 8(10) (2008) 3498-3502.

[48] A. Ambrosi, C.K. Chua, A. Bonanni, M. Pumera, Electrochemistry of graphene and related materials, Chem. Rev. 114(14) (2014) 7150-7188.

[49] M. Yi, Z. Shen, A review on mechanical exfoliation for the scalable production of graphene, J. Mater. Chem. A 3(22) (2015) 11700-11715.

[50] W. Yang, G. Chen, Z. Shi, C.-C. Liu, L. Zhang, G. Xie, M. Cheng, D. Wang, R. Yang, D. Shi, K. Watanabe, T. Taniguchi, Y. Yao, Y. Zhang, G. Zhang, Epitaxial growth of single-domain graphene on hexagonal boron nitride, Nat. Mater. 12 (2013) 792.

[51] M. Losurdo, M.M. Giangregorio, P. Capezzuto, G. Bruno, Graphene CVD growth on copper and nickel: role of hydrogen in kinetics and structure, Phys. Chem. Chem. Phys. 13(46) (2011) 20836-20843.

[52] R. Muñoz, C. Gómez-Aleixandre, Review of CVD synthesis of graphene, Adv. Sci. 19(10-11-12) (2013) 297322.

[53] A.O. Osikoya, O. Parlak, N.A. Murugan, E.D. Dikio, H. Moloto, L. Uzun, A.P.F. Turner, A. Tiwari, Acetylenesourced CVD-synthesised catalytically active graphene for electrochemical biosensing, Biosens. Bioelectron. 89 (2017) 496-504.

[54] Y.H. Kwak, D.S. Choi, Y.N. Kim, H. Kim, D.H. Yoon, S.-S. Ahn, J.-W. Yang, W.S. Yang, S. Seo, Flexible glucose sensor using CVD-grown graphene-based field effect transistor, Biosens. Bioelectron. 37(1) (2012) 82-87.

[55] D.B. Shinde, J. Debgupta, A. Kushwaha, M. Aslam, V.K. Pillai, Electrochemical unzipping of multi-walled carbon nanotubes for facile synthesis of high-quality graphene nanoribbons, J. Am. Chem. Soc. 133(12) (2011) 4168-4171.

[56] Y. Zhang, M. Chu, L. Yang, Y. Tan, W. Deng, M. Ma, X. Su, Q. Xie, Three-dimensional graphene networks as a new substrate for immobilization of laccase and dopamine and its application in glucose/O2 biofuel cell, ACS Appl. Mater. Inter. 6(15) (2014) 12808-12814.

[57] J. Tang, R.M.L. Werchmeister, L. Preda, W. Huang, Z. Zheng, S. Leimkühler, U. Wollenberger, X. Xiao, C. Engelbrekt, J. Ulstrup, J. Zhang, Three-dimensional sulfite oxidase bioanodes based on graphene functionalized carbon paper for sulfite/O2 biofuel cells, ACS Catal. 9(7) (2019) 6543-6554.

[58] O.C. Compton, S.T. Nguyen, Graphene oxide, highly reduced graphene oxide, and graphene: versatile building blocks for carbon-Based materials, Small 6(6) (2010) 711-723.

[59] W. Chen, L. Yan, P.R. Bangal, Preparation of graphene by the rapid and mild thermal reduction of graphene oxide induced by microwaves, Carbon 48(4) (2010) 1146-1152.

[60] C.K. Chua, M. Pumera, Chemical reduction of graphene oxide: a synthetic chemistry viewpoint, Chem. Soc. Rev. 43(1) (2014) 291-312.

[61] Y. Li, K. Sheng, W. Yuan, G. Shi, A high-performance flexible fibre-shaped electrochemical capacitor based on electrochemically reduced graphene oxide, Chem. Commun. 49(3) (2013) 291-293. 
[62] A. Koushanpour, N. Guz, M. Gamella, E. Katz, Graphene-functionalized 3D-carbon fiber electrodes preparation and electrochemical characterization, Electroanal. 28(9) (2016) 1943-1946.

[63] X. Wang, J. Wang, H. Cheng, P. Yu, J. Ye, L. Mao, Graphene as a spacer to layer-by-layer assemble electrochemically functionalized nanostructures for molecular bioelectronic devices, Langmuir 27(17) (2011) 11180-11186.

[64] X. Dong, X. Wang, L. Wang, H. Song, H. Zhang, W. Huang, P. Chen, 3D graphene foam as a monolithic and macroporous carbon electrode for electrochemical sensing, ACS Appl. Mater. Inter. 4(6) (2012) 3129-3133.

[65] F. Shen, D. Pankratov, A. Halder, X. Xiao, M.D. Toscano, J. Zhang, J. Ulstrup, L. Gorton, Q. Chi, Twodimensional graphene paper supported flexible enzymatic fuel cells, Nanoscale Adv. 1(7) (2019) 2562-2570. [66] S. Wei, Y. Hao, Z. Ying, C. Xu, Q. Wei, S. Xue, H.-M. Cheng, W. Ren, L.-P. Ma, Y. Zeng, Transfer-free CVD graphene for highly sensitive glucose sensors, J. Mater. Sci. Technol. 37 (2020) 71-76.

[67] I.V. Pavlidis, M. Patila, U.T. Bornscheuer, D. Gournis, H. Stamatis, Graphene-based nanobiocatalytic systems: recent advances and future prospects, Trends Biotechnol. 32(6) (2014) 312-320.

[68] M. Zhou, Y. Zhai, S. Dong, Electrochemical sensing and biosensing platform based on chemically reduced graphene oxide, Anal. Chem. 81(14) (2009) 5603-5613.

[69] B. Unnikrishnan, S. Palanisamy, S.-M. Chen, A simple electrochemical approach to fabricate a glucose biosensor based on graphene-glucose oxidase biocomposite, Biosens. Bioelectron. 39(1) (2013) 70-75.

[70] N. Lalaoui, A. Le Goff, M. Holzinger, M. Mermoux, S. Cosnier, Wiring laccase on covalently modified graphene: carbon nanotube assemblies for the direct bio-electrocatalytic reduction of oxygen, Chem-Eur. J. 21(8) (2015) 3198-3201.

[71] Y. Umasankar, B.-R. Adhikari, A. Chen, Effective immobilization of alcohol dehydrogenase on carbon nanoscaffolds for ethanol biofuel cell, Bioelectrochemistry 118 (2017) 83-90.

[72] P. Gai, Y. Ji, Y. Chen, C. Zhu, J. Zhang, J.-J. Zhu, A nitrogen-doped graphene/gold nanoparticle/formate dehydrogenase bioanode for high power output membrane-less formic acid/O2 biofuel cells, Analyst 140(6) (2015) 1822-1826.

[73] A. Ahmadian Yazdi, J. Xu, Nitrogen-doped graphene approach to enhance the performance of a membraneless enzymatic biofuel cell, Front. Energy 12(2) (2018) 233-238.

[74] C. Zhang, N. Mahmood, H. Yin, F. Liu, Y. Hou, Synthesis of phosphorus-doped graphene and its multifunctional applications for oxygen reduction reaction and lithium Ion batteries, Adv. Mater. 25(35) (2013) 4932-4937.

[75] J. Han, L.L. Zhang, S. Lee, J. Oh, K.-S. Lee, J.R. Potts, J. Ji, X. Zhao, R.S. Ruoff, S. Park, Generation of Bdoped graphene nanoplatelets using a solution process and their supercapacitor applications, ACS Nano 7(1) (2013) 19-26.

[76] S. Gong, Q. Wang, Boron-doped graphene as a promising anode material for potassium-ion batteries with a large capacity, high rate performance, and good cycling stability, J. Phys. Chem. C 121(44) (2017) 24418-24424.

[77] M. Li, C. Liu, H. Zhao, H. An, H. Cao, Y. Zhang, Z. Fan, Tuning sulfur doping in graphene for highly sensitive dopamine biosensors, Carbon 86 (2015) 197-206.

[78] F. Shahzad, S.A. Zaidi, C.M. Koo, Synthesis of multifunctional electrically tunable fluorine-doped reduced graphene oxide at low temperatures, ACS Appl. Mater. Inter. 9(28) (2017) 24179-24189.

[79] H. Liu, Y. Liu, D. Zhu, Chemical doping of graphene, J. Mater. Chem. 21(10) (2011) 3335-3345.

[80] Y. Wang, Y. Shao, D.W. Matson, J. Li, Y. Lin, Nitrogen-doped graphene and its application in electrochemical biosensing, ACS Nano 4(4) (2010) 1790-1798.

[81] H. Zhang, L. Zhang, Y. Han, Y. Yu, M. Xu, X. Zhang, L. Huang, S. Dong, RGO/Au NPs/N-doped CNTs supported on nickel foam as an anode for enzymatic biofuel cells, Biosens. Bioelectron. 97 (2017) 34-40.

[82] C.-e. Zhao, P. Gai, R. Song, Y. Chen, J. Zhang, J.-J. Zhu, Nanostructured material-based biofuel cells: recent advances and future prospects, Chem. Soc. Rev. 46(5) (2017) 1545-1564.

[83] L. Dai, Graphene: Tunable superdoping, Nat. Energy 1(4) (2016) 16041.

[84] K. Gong, F. Du, Z. Xia, M. Durstock, L. Dai, Nitrogen-doped carbon nanotube arrays with high electrocatalytic activity for oxygen reduction, Science 323(5915) (2009) 760-764.

[85] L.S. Panchakarla, K.S. Subrahmanyam, S.K. Saha, A. Govindaraj, H.R. Krishnamurthy, U.V. Waghmare, C.N.R. Rao, Synthesis, structure, and properties of boron- and nitrogen-doped graphene, Adv. Mater. 21(46) (2009) 4726-4730.

[86] T. Van Tam, S.G. Kang, K.F. Babu, E.-S. Oh, S.G. Lee, W.M. Choi, Synthesis of B-doped graphene quantum dots as a metal-free electrocatalyst for the oxygen reduction reaction, J. Mater. Chem. A 5(21) (2017) 10537-10543. 
[87] V. Urbanová, F. Karlický, A. Matěj, F. Šembera, Z. Janoušek, J.A. Perman, V. Ranc, K. Čépe, J. Michl, M. Otyepka, R. Zbořil, Fluorinated graphenes as advanced biosensors - effect of fluorine coverage on electron transfer properties and adsorption of biomolecules, Nanoscale 8(24) (2016) 12134-12142.

[88] C. Di Bari, A. Goñi-Urtiaga, M. Pita, S. Shleev, M.D. Toscano, R. Sainz, A.L. De Lacey, Fabrication of high surface area graphene electrodes with high performance towards enzymatic oxygen reduction, Electrochim. Acta 191 (2016) 500-509.

[89] V. Georgakilas, M. Otyepka, A.B. Bourlinos, V. Chandra, N. Kim, K.C. Kemp, P. Hobza, R. Zboril, K.S. Kim, Functionalization of graphene: covalent and non-covalent approaches, derivatives and applications, Chem. Rev. 112(11) (2012) 6156-6214.

[90] S. Niyogi, E. Bekyarova, M.E. Itkis, H. Zhang, K. Shepperd, J. Hicks, M. Sprinkle, C. Berger, C.N. Lau, W.A. deHeer, E.H. Conrad, R.C. Haddon, Spectroscopy of covalently functionalized graphene, Nano Lett. 10(10) (2010) 4061-4066.

[91] A. Sinitskii, A. Dimiev, D.A. Corley, A.A. Fursina, D.V. Kosynkin, J.M. Tour, Kinetics of diazonium functionalization of chemically converted graphene nanoribbons, ACS Nano 4(4) (2010) 1949-1954.

[92] Z. Xu, S. Wang, Y. Li, M. Wang, P. Shi, X. Huang, Covalent functionalization of graphene oxide with biocompatible poly(ethylene glycol) for delivery of paclitaxel, ACS Appl. Mater. Inter. 6(19) (2014) 17268-17276. [93] C. Shan, H. Yang, D. Han, Q. Zhang, A. Ivaska, L. Niu, Water-soluble graphene covalently functionalized by biocompatible poly-l-lysine, Langmuir 25(20) (2009) 12030-12033.

[94] S. Park, D.A. Dikin, S.T. Nguyen, R.S. Ruoff, Graphene oxide sheets chemically cross-linked by polyallylamine, J. Phys. Chem. C 113(36) (2009) 15801-15804.

[95] H.J. Salavagione, M.A. Gómez, G. Martínez, Polymeric modification of graphene through esterification of graphite oxide and poly(vinyl alcohol), Macromolecules 42(17) (2009) 6331-6334.

[96] S. Korkut, M.S. Kilic, S. Uzuncar, B. Hazer, Novel graphene-modified poly(styrene-b-isoprene-b-styrene) enzymatic fuel cell with operation in plant leaves, Anal. Lett. 49(14) (2016) 2322-2336.

[97] N. Kaur, A. Bharti, S. Batra, S. Rana, S. Rana, A. Bhalla, N. Prabhakar, An electrochemical aptasensor based on graphene doped chitosan nanocomposites for determination of Ochratoxin A, Microchem. J. 144 (2019) 102-109. [98] E.E. Tkalya, M. Ghislandi, G. de With, C.E. Koning, The use of surfactants for dispersing carbon nanotubes and graphene to make conductive nanocomposites, Curr. Opin. Colloid In. 17(4) (2012) 225-232.

[99] Z. Kang, K. Jiao, X. Xu, R. Peng, S. Jiao, Z. Hu, Graphene oxide-supported carbon nanofiber-like network derived from polyaniline: A novel composite for enhanced glucose oxidase bioelectrode performance, Biosens. Bioelectron. 96 (2017) 367-372.

[100] A.S. Campbell, Y.J. Jeong, S.M. Geier, R.R. Koepsel, A.J. Russell, M.F. Islam, Membrane/mediator-free rechargeable enzymatic biofuel cell utilizing graphene/single-wall carbon nanotube cogel electrodes, ACS Appl. Mater. Inter. 7(7) (2015) 4056-4065.

[101] M. Fang, J. Long, W. Zhao, L. Wang, G. Chen, pH-Responsive chitosan-mediated graphene dispersions, Langmuir 26(22) (2010) 16771-16774.

[102] D. Wang, Y. Li, P. Hasin, Y. Wu, Preparation, characterization, and electrocatalytic performance of graphenemethylene blue thin films, Nano. Res. 4(1) (2011) 124-130.

[103] H. Liu, J. Gao, M. Xue, N. Zhu, M. Zhang, T. Cao, Processing of graphene for electrochemical application: noncovalently functionalize graphene sheets with water-soluble electroactive methylene green, Langmuir 25(20) (2009) 12006-12010.

[104] P. Bollella, G. Fusco, D. Stevar, L. Gorton, R. Ludwig, S. Ma, H. Boer, A. Koivula, C. Tortolini, G. Favero, R. Antiochia, F. Mazzei, A glucose/oxygen enzymatic fuel cell based on gold nanoparticles modified graphene screen-printed electrode. Proof-of-concept in human Saliva, Sensor. Actuat. B-Chem. 256 (2018) 921-930.

[105] B. Liang, X. Guo, L. Fang, Y. Hu, G. Yang, Q. Zhu, J. Wei, X. Ye, Study of direct electron transfer and enzyme activity of glucose oxidase on graphene surface, Electrochem. Commun. 50 (2015) 1-5.

[106] G.-X. Wang, Y. Qian, X.-X. Cao, X.-H. Xia, Direct electrochemistry of cytochrome c on a graphene/poly (3,4-ethylenedioxythiophene) nanocomposite modified electrode, Electrochem. Commun. 20 (2012) 1-3.

[107] F. Shen, D. Pankratov, G. Pankratova, M.D. Toscano, J. Zhang, J. Ulstrup, Q. Chi, L. Gorton, Supercapacitor/biofuel cell hybrid device employing biomolecules for energy conversion and charge storage, Bioelectrochemistry 128 (2019) 94-99.

[108] A.-J. Shen, D.-L. Li, X.-J. Cai, C.-Y. Dong, H.-Q. Dong, H.-Y. Wen, G.-H. Dai, P.-J. Wang, Y.-Y. Li, Multifunctional nanocomposite based on graphene oxide for in vitro hepatocarcinoma diagnosis and treatment, $\mathrm{J}$. Biomed. Mater. Res. 100A(9) (2012) 2499-2506.

[109] S. Alwarappan, A. Erdem, C. Liu, C.-Z. Li, Probing the electrochemical properties of graphene nanosheets for biosensing applications, J. Phys. Chem. C 113(20) (2009) 8853-8857. 
[110] L. Xu, N. Wei, Y. Zheng, Z. Fan, H.-Q. Wang, J.-C. Zheng, Graphene-nanotube 3D networks: intriguing thermal and mechanical properties, J. Mater. Chem. 22(4) (2012) 1435-1444.

[111] C. Liu, S. Alwarappan, Z. Chen, X. Kong, C.-Z. Li, Membraneless enzymatic biofuel cells based on graphene nanosheets, Biosens. Bioelectron. 25(7) (2010) 1829-1833.

[112] L. Tang, Y. Wang, Y. Li, H. Feng, J. Lu, J. Li, Preparation, structure, and electrochemical properties of reduced graphene sheet films, Adv. Funct. Mater. 19(17) (2009) 2782-2789.

[113] J. Jia, D. Kato, R. Kurita, Y. Sato, K. Maruyama, K. Suzuki, S. Hirono, T. Ando, O. Niwa, Structure and electrochemical properties of carbon films prepared by a electron cyclotron resonance sputtering method, Anal. Chem. 79(1) (2007) 98-105.

[114] C. Soldano, A. Mahmood, E. Dujardin, Production, properties and potential of graphene, Carbon 48(8) (2010) 2127-2150.

[115] Y. Qian, I.M. Ismail, A. Stein, Ultralight, high-surface-area, multifunctional graphene-based aerogels from self-assembly of graphene oxide and resol, Carbon 68 (2014) 221-231.

[116] Z. Xu, Y. Zhang, P. Li, C. Gao, Strong, conductive, lightweight, neat graphene aerogel fibers with aligned pores, ACS Nano 6(8) (2012) 7103-7113.

[117] Q. Jiang, Y. Zhao, Effects of activation conditions on BET specific surface area of activated carbon nanotubes, Micropor. Mesopor. Mat. 76(1) (2004) 215-219.

[118] R.R. Bacsa, C. Laurent, A. Peigney, W.S. Bacsa, T. Vaugien, A. Rousset, High specific surface area carbon nanotubes from catalytic chemical vapor deposition process, Chem. Phys. Lett. 323(5) (2000) 566-571.

[119] Z.-X. Cai, X.-H. Song, Y.-Y. Chen, Y.-R. Wang, X. Chen, 3D nitrogen-doped graphene aerogel: a low-cost, facile prepared direct electrode for H2O2 sensing, Sensor. Actuat. B-Chem. 222 (2016) 567-573.

[120] B. Wang, S. Yan, Y. Shi, Direct electrochemical analysis of glucose oxidase on a graphene aerogel/gold nanoparticle hybrid for glucose biosensing, J. Solid State Electr. 19(1) (2015) 307-314.

[121] Y. Song, C. Chen, C. Wang, Graphene/enzyme-encrusted three-dimensional carbon micropillar arrays for mediatorless micro-biofuel cells, Nanoscale 7(16) (2015) 7084-7090.

[122] V. Mani, R. Devasenathipathy, S.-M. Chen, J.-A. Gu, S.-T. Huang, Synthesis and characterization of graphene-cobalt phthalocyanines and graphene-iron phthalocyanine composites and their enzymatic fuel cell application, Renew. Energ. 74 (2015) 867-874.

[123] Á. Torrinha, M.C.B.S.M. Montenegro, A.N. Araújo, Conjugation of glucose oxidase and bilirubin oxidase bioelectrodes as biofuel cell in a finger-powered microfluidic platform, Electrochim. Acta 318 (2019) 922-930

[124] A. Koushanpour, M. Gamella, N. Guz, E. Katz, A biofuel cell based on biocatalytic reactions of glucose on both anode and cathode electrodes, Electroanal. 29(4) (2017) 950-954.

[125] A. Koushanpour, M. Gamella, E. Katz, A biofuel cell based on biocatalytic reactions of lactate on both anode and cathode electrodes - extracting electrical power from human sweat, Electroanal. 29(6) (2017) 1602-1611.

[126] A. Koushanpour, M. Gamella, Z. Guo, E. Honarvarfard, A. Poghossian, M.J. Schöning, K. Alexandrov, E.

Katz, Ca2+-switchable glucose dehydrogenase sssociated with electrochemical/electronic interfaces: applications to signal-controlled power production and biomolecular release, J. Phys. Chem. B 121(51) (2017) 11465-11471.

[127] A. Koushanpour, N. Guz, M. Gamella, E. Katz, Biofuel cell based on carbon fiber electrodes functionalized with graphene nanosheets, ECS J. Solid State Sc. 5(8) (2016) M3037-M3040.

[128] K. Hoshi, K. Muramatsu, H. Sumi, Y. Nishioka, Graphene-coated carbon fiber cloth for flexible electrodes of glucose fuel cells, Jpn. J. Appl. Phys. 55(2S) (2016) $02 B E 05$.

[129] N. Maleki, S. Kashanian, M. Nazari, N. Shahabadi, A novel and enhanced membrane-free performance of glucose/O2 biofuel cell, integrated with biocompatible laccase nanoflower biocathode and glucose dehydrogenase bioanode, IEEE Sens. J. (2019) 1-1.

[130] R.M.L. Werchmeister, J. Tang, X. Xiao, U. Wollenberger, H.A. Hjuler, J. Ulstrup, J. Zhang, Threedimensional bioelectrodes utilizing graphene based bioink, J. Electrochem. Soc. 166(16) (2019) G170-G177. [131] X. Xiao, M.e. Wang, H. Li, Y. Pan, P. Si, Non-enzymatic glucose sensors based on controllable nanoporous gold/copper oxide nanohybrids, Talanta 125 (2014) 366-371.

[132] P.N. Bartlett, F.A. Al-Lolage, There is no evidence to support literature claims of direct electron transfer (DET) for native glucose oxidase (GOx) at carbon nanotubes or graphene, J. Electroanal. Chem. 819 (2018) 26-37. [133] R.D. Milton, F. Wu, K. Lim, S. Abdellaoui, D.P. Hickey, S.D. Minteer, Promiscuous glucose oxidase: electrical energy conversion of multiple polysaccharides spanning starch and dairy milk, ACS Catal. 5(12) (2015) 7218-7225.

[134] I. Jeerapan, J.R. Sempionatto, A. Pavinatto, J.-M. You, J. Wang, Stretchable biofuel cells as wearable textilebased self-powered sensors, J. Mater. Chem. A 4(47) (2016) 18342-18353. 
[135] T. Zeng, D. Pankratov, M. Falk, S. Leimkühler, S. Shleev, U. Wollenberger, Miniature direct electron transfer based sulphite/oxygen enzymatic fuel cells, Biosens. Bioelectron. 66(Supplement C) (2015) 39-42.

[136] M.S. Thorum, C.A. Anderson, J.J. Hatch, A.S. Campbell, N.M. Marshall, S.C. Zimmerman, Y. Lu, A.A. Gewirth, Direct, electrocatalytic oxygen reduction by laccase on anthracene-2-methanethiol-modified gold, J. Phys. Chem. Lett. 1(15) (2010) 2251-2254.

[137] S. Shleev, A. Jarosz-Wilkolazka, A. Khalunina, O. Morozova, A. Yaropolov, T. Ruzgas, L. Gorton, Direct electron transfer reactions of laccases from different origins on carbon electrodes, Bioelectrochemistry 67(1) (2005) $115-24$.

[138] S. Shleev, A. El Kasmi, T. Ruzgas, L. Gorton, Direct heterogeneous electron transfer reactions of bilirubin oxidase at a spectrographic graphite electrode, Electrochem. Commun. 6(9) (2004) 934-939.

[139] C. Abreu, Y. Nedellec, O. Ondel, F. Buret, S. Cosnier, A. Le Goff, M. Holzinger, Glucose oxidase bioanodes for glucose conversion and $\mathrm{H} 2 \mathrm{O} 2$ production for horseradish peroxidase biocathodes in a flow through glucose biofuel cell design, J. Power Sources 392 (2018) 176-180.

[140] P. Cinquin, C. Gondran, F. Giroud, S. Mazabrard, A. Pellissier, F. Boucher, J.-P. Alcaraz, K. Gorgy, F. Lenouvel, S. Mathé, P. Porcu, S. Cosnier, A Glucose BioFuel Cell Implanted in Rats, PLOS ONE 5(5) (2010) e10476.

[141] S. El Ichi-Ribault, J.-P. Alcaraz, F. Boucher, B. Boutaud, R. Dalmolin, J. Boutonnat, P. Cinquin, A. Zebda, D.K. Martin, Remote Wireless Control of An Enzymatic Biofuel Cell Implanted in A Rabbit for 2 Months, Electrochim. Acta 269 (2018) 360-366.

[142] T. Miyake, K. Haneda, N. Nagai, Y. Yatagawa, H. Onami, S. Yoshino, T. Abe, M. Nishizawa, Enzymatic Biofuel Cells Designed for Direct Power Generation from Biofluids in Living Organisms, Energy Environ. Sci. 4(12) (2011) 5008-5012.

[143] X. Peng, T. Hu, T. Bao, L. Zhao, X. Zeng, W. Wen, X. Zhang, S. Wang, A label-free electrochemical biosensor for methyltransferase activity detection and inhibitor screening based on graphene quantum dot and enzyme-catalyzed reaction, J. Electroanal. Chem. 799 (2017) 327-332.

[144] A. Nasar, R. Perveen, Applications of enzymatic biofuel cells in bioelectronic devices - A review, Int. J. Hydrogen Energ. 44(29) (2019) 15287-15312. 


\section{Highlights}

- Recent research progress in fabrication of graphene-based electrodes is reviewed

- Features of graphene-based electrodes crucial for bioelectrochemistry are highlighted

- Reports on graphene-based enzymatic biofuel cells of the last 5 years are summarized

- Perspectives for graphene-based enzymatic biofuel cells are offered

\section{Declaration of interests}

$\bigotimes$ The authors declare that they have no known competing financial interests or personal relationships that could have appeared to influence the work reported in this paper.

$\square$ The authors declare the following financial interests/personal relationships which may be considered as potential competing interests: 